\title{
The Mexican Pension Annuity Market
}

\author{
Gregorio Impavido ${ }^{\dagger}$
}

\author{
The World Bank Group
}

\begin{abstract}
This paper analyzes the performance and development of the Mexican pension annuity market established as a consequence of the 1997 pension reform. The Mexican experience displays interesting characteristics providing lessons for other countries that still need to design the decumulation phase of their newly established second pillars. At the same, time it raises some technical and policy concerns that need addressing as they could hamper, in the future, the healthy development of the market. The paper concludes that: 1) general life insurance companies may better hedge longevity risk than specialized annuity companies; 2) competition should be based on prices rather than additional products; 3) better disclosure of options under the 1973 and 1997 social security laws should be given to disability and life annuitants; and 4) various measures should be taken to improve asset liability management including allowing companies to trade over the counter derivatives and substituting over time the regulatory asset liability management framework with an economic asset liability management framework.
\end{abstract}

JEL Classification Codes: G15, G18, G22, G23, G28.

Keywords: Mexico, Pension, Annuity Markets, Financial Sector Development.

World Bank Policy Research Working Paper 4236, May 2007

The Policy Research Working Paper Series disseminates the findings of work in progress to encourage the exchange of ideas about development issues. An objective of the series is to get the findings out quickly, even if the presentations are less than fully polished. The papers carry the names of the authors and should be cited accordingly. The findings, interpretations, and conclusions expressed in this paper are entirely those of the authors. They do not necessarily represent the view of the World Bank, its Executive Directors, or the countries they represent. Policy Research Working Papers are available online at http://econ.worldbank.org

\footnotetext{
${ }^{\dagger}$ Gregorio Impavido (gimpavido@worldbank.org) is Senior Financial Economist at the World Bank. This paper benefited from comments received by SHCP, by Manuel Aguilera, Norma Alicia Rosas, Manuel Calderón, Héctor Rodríguez-Cabo (all CNSF), and Augusto de la Torre (World Bank). This paper reflects the view of its author, not necessarily those of the affiliation institution.
} 


\section{TABLE OF CONTENTS}

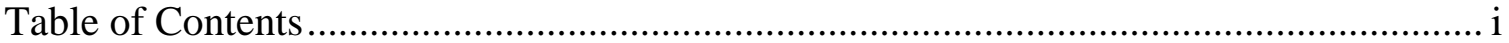

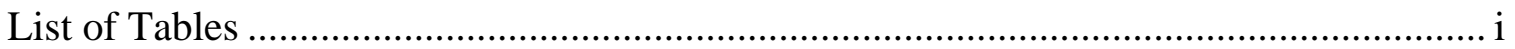

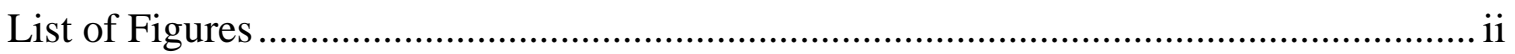

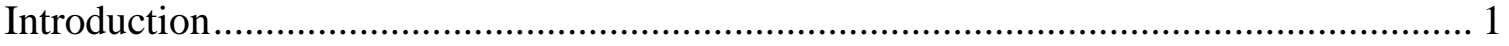

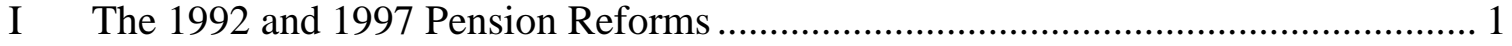

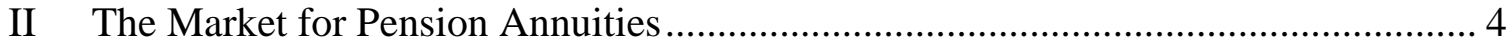

II.A Market Structure and Growth ..................................................................... 4

II.B Pension Annuity Products, Pricing, and Competition ...................................... 7

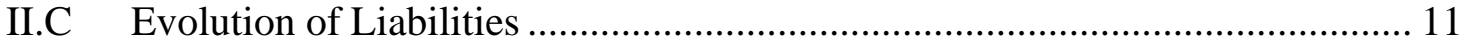

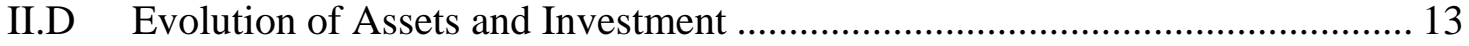

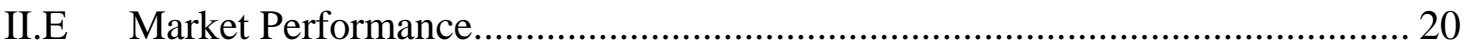

III Development Prospects For The Pension Annuity Market.................................. 28

Conclusions and Policy Considerations..................................................................... 34

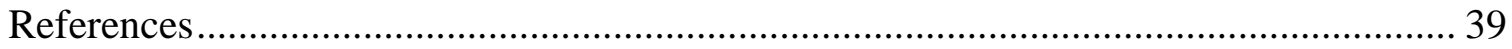

APPENDIX A : Regulatory Framework for Pension Annuities.................................... 41

APPENDIX B : List of Acronyms ............................................................................ 44

\section{LIST OF TABLES}

Table 1: Contributions Under SAR-92 and SAR-97 (Percentage of Base Salary)............. 2

Table 2: Accumulated Savings in the AFORE System ................................................. 3

Table 3: Transitional and New Generations in the Pension System (Year 2004) ............. 4

Table 4: Pension Annuity Providers and 2005 Market Shares (Percentage of Market

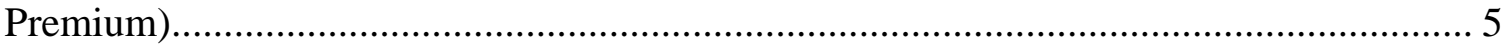

Table 5: Evolution of Market Structure, 1997-2005 ….................................................. 5

Table 6: Insurance Sector Business Lines Growth, 1997-2005 ....................................... 6

Table 7: Pension Annuity Market Growth, 1997-2005................................................. 7

Table 8: Evolution of Separate Technical Provisions, 1997-2005 (MXN mln.).............. 12

Table 9: Investment Limits by Type of Security for Technical Provisions ...................... 15

Table 10: Investment Limits by Type of Issuer for Technical Provisions....................... 16

Table 11: Investment of Technical Provisions, 1997-2005.......................................... 17

Table 12: Inflation and Currency Risk in Technical Provisions, 1997-2005................... 17

Table 13: Average Maturity of Government Bond Portfolio (Years).............................. 18

Table 14: Average Maturity of Private Sector Bond Portfolio (Years) ........................... 18

Table 15: Evolution of Average Underwriting Costs, MXN Million, 2001-2005........... 22

Table 16: Evolution of Average Non-Life Loss Ratios in Select Countries (in Percent). 23

Table 17: Weighting System for Asset Liability Mismatches ....................................... 26

Table 18: Pension Annuities Solvency and Profitability Indicators (1997-2005) ........... 27

Table 19: Disability Benefits Under LSS-73 and LSS-97 .......................................... 30

Table 20: Monthly Disability Benefit Comparison Under 1973 and 1997 Laws (MXN )31

Table 21: Choice of IV Benefits Under LSS-73 and LSS-97 For Transitional Cohort.... 33

Table 22: Regulatory Framework for Pension Annuities (as of May 2006).................... 41 


\section{LIST OF FIGURES}

Figure 1: Evolution of Total Technical Provisions (Real 2005 MXN mln.) .................... 12

Figure 2: Evolution and Financing of Total Assets (Real 2005 MXN mln.).................... 14

Figure 3: Evolution of Average Underwriting Performance ......................................... 22

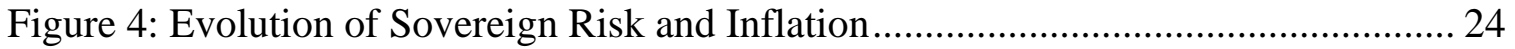

Figure 5: Evolution of Investment Performance and Key Interest Rates ........................ 25

Figure 6: Impact of SAR-02 Reform on IV Premium Growth ..................................... 31 


\section{INTRODUCTION}

This paper analyzes the performance and development of the Mexican pension annuity market established as a consequence of the 1997 pension reform. The Mexican experience displays interesting characteristics providing lessons for other countries that still need to design the decumulation phase of their newly established second pillars. At the same time, it raises some technical and policy concerns that need addressing as they could hamper, in the future, the healthy development of the market.

This paper benefited from interviews with officials in the Insurance Supervisory Authority (CNSF), the Ministry of Finance (SHCP), the Pension Supervisory Authority (CONSAR) and the Social Security Institute (IMSS) as well as with management of specialized annuity companies. It could not have been prepared without the written material provided by the CNSF, listed in the reference section at the end of the paper.

The reminder of the paper is structured as follows. Section I briefly summarizes the 1992 and 1997 pension reforms from which the pension annuity market derives. Section II analyzes issues related to: 1) the evolution of the annuity market industrial organization; 2) annuity product design and competition; 3) the evolution of assets and liabilities of specialized annuity companies; 4) the evolution of the regulatory framework; and 5) the performance of the market. Section III analyzes the development prospects of the market in light of the 2001 and 2002 amendments of the 1997 social security law. Conclusions and policy recommendations follow.

\section{ThE 1992 AND 1997 PENSION RefORMS}

In 1992, Mexico reformed the pension system for workers in the private sector ${ }^{1}$ and in the public sector ${ }^{2}$ introducing mandatory defined contribution individual accounts complementary to the existing independent defined benefit schemes for public and private workers. The reform is known as SAR-92. In December 1995, a proposal for a new Ley del Seguro Social (LSS-97) was submitted to Congress. This was passed in the same month and was effective as of July 1997. The reform of 1997 is known as SAR-97 and covered only private sector workers. The main component of the second reform was the abolition of the old age defined benefit scheme for private sector workers. As of today, pubic sector workers are still covered by a defined benefit scheme.

Table 1 summarizes the impact that the SAR-92 and SAR-97 reforms had on the old benefits managed by the IMSS. The same table lists in column one the five subaccounts for the various benefits provided by the system, these listed in column two. The SAR-92 established two individual accounts for old age (retiro) benefits and housing (vivienda). The SAR-97 reformed the old defined benefits of disability, old age, and life managed by the IMSS. These were divided into two separate lines of benefits for old age (retiro) and severance at advanced age (cesantía en edad avanzada y vejez) in the RCV subaccount, on the one hand, and disability and life (invalidez y vida) in the IV subaccount, on the other hand.

\footnotetext{
${ }^{1}$ Private sector workers are covered by the Instituto Mexicano del Seguro Social (IMSS).

${ }^{2}$ Public sector workers at the federal level are covered by the Instituto De Seguridad Y Servicios Sociales De Los Trabajadores Del Estado (ISSSTE).
} 
Old age benefits (subaccount RCV) are now defined contribution benefits based on individual accounts managed by dedicated pension fund administrators (AFOREs) with monies invested in legally independent and dedicated pension mutual funds (SIEFOREs) under the supervision of a dedicated pension supervisor (CONSAR). Contributions to the RCV account amount to 6.5 percent of the worker's base salary plus a flat contribution from the federal government of MXN 2.76 per working day as of end of 2005. Disability, life and survivorship benefits (subaccount IV) are still defined benefit administered by the IMSS but with a revised benefit formula. Contributions to the IMSS for this line of benefit amount to 2.5 percent of the worker's base salary. Workers' compensation (subaccount RT) remains administered by the IMSS with variable contributions as defined in Article 72 of LSS-97. Finally, housing (subaccount V) contributions amount to 5 percent of the worker's base salary and are managed by the housing financial agency for private sector workers (INFONAVIT) while AFOREs conduct record keeping for this account.

Table 1: Contributions Under SAR-92 and SAR-97 (Percentage of Base Salary)

\begin{tabular}{|c|c|c|c|c|}
\hline Subaccount & & $\begin{array}{c}\text { SAR-92 } \\
\text { Period } \\
1992- \\
1997\end{array}$ & $\begin{array}{c}\text { SAR-97 } \\
\text { Period } \\
\text { 1997 - onwards }\end{array}$ & $\begin{array}{c}\text { Managed during } \\
\text { accumulation period } \\
\text { by: }\end{array}$ \\
\hline \multirow{3}{*}{ RCV } & Retiro 1/ & 2.0 percent & 2.0 percent & \multirow{3}{*}{$\begin{array}{l}\text { AFOREs, } \\
\text { SIEFOREs }\end{array}$} \\
\hline & Cesantía y Vejez 2/ & & 4.5 percent & \\
\hline & Cuota Social 3/ & & $\begin{array}{c}\text { MXN } 2.76 \text { per working } \\
\text { day }\end{array}$ & \\
\hline IV & Invalidez y Vida 4/ & 2.5 percent & 2.5 percent & IMSS \\
\hline RT & $\begin{array}{l}\text { Riesgo de Trabajo } \\
\text { 5/ }\end{array}$ & n.a. & $\begin{array}{c}\text { Min. } 0.25 \text { percent, } \\
\text { Max. } 15 \text { percent }\end{array}$ & IMSS \\
\hline $\mathbf{V}$ & Vivienda 1/ & 5.0 percent & 5.0 percent & $\begin{array}{c}\text { AFOREs, } \\
\text { INFONAVIT }\end{array}$ \\
\hline
\end{tabular}

Notes: 1/ Employer funds 100 percent of this contribution; 2/ Employer funds 3.15 percent, employee funds

1.125 percent, federal government funds 0.225 percent; 3 / federal government funds 100 percent of this contribution. The value reported is indicative of end of 2005. This is indexed to inflation and updated every quarter; 4/ Employer funds 1.75 percent, employee funds 0.625 percent, federal government funds 0.125 percent; Minimum and maximum as defined in Article 72 of LSS-97.

Source: IMSS, CONSAR.

As far as the accumulation phase is concerned, Table 2 summarizes the growth of the AFORE system since the 1997 reform. Currently around 10 percent of GDP is accumulated in the new system. To these reserves, it is necessary to add the reserves accumulated by the IMSS for the lines of benefits of IV and RT to have a sense of the potential demand for annuity products that can be provided by the private sector.

As far as the decumulation phase is concerned, the SAR-97 reform treats differently members of the "transition cohort" from members of the "new cohort." If a new entrant to the labor force after July 1997 (the so called "new cohort”) becomes disabled or dies, she or her beneficiaries must buy an annuity from a private insurance sector specialized annuity provider. If a member of the new cohort retires at old age (65 years or older) or due to severance at old age (at least 60 years old) she can choose between a programmed 
withdrawal offered by an AFORE or an annuity offered by a specialized annuity provider. It is important to mention that, if the accumulated balance at retirement is less than what is needed to obtain an annuity greater than or equal to the minimum guaranteed pension (PMG), the worker is required to select a programmed withdrawal. When resources are exhausted, the government is responsible for paying the PMG to the worker. ${ }^{3}$

Table 2: Accumulated Savings in the AFORE System

\begin{tabular}{cccccc}
\hline $\begin{array}{c}\text { Year } \\
\mathbf{1} /\end{array}$ & $\begin{array}{c}\text { Number of } \\
\text { AFOREs }\end{array}$ & $\begin{array}{c}\text { RCV } \\
\text { account } \\
\text { (MXN 000,000) }\end{array}$ & $\begin{array}{c}\text { Voluntary } \\
\text { account } \\
\text { (MXN 000,000) }\end{array}$ & $\begin{array}{c}\text { Housing } \\
\text { account } \\
\text { (MXN 000,000) }\end{array}$ & $\begin{array}{c}\text { Total } \\
\text { (\% of GDP) }\end{array}$ \\
\hline 1998 & 13 & $54,470.5$ & 46.7 & $51,419.0$ & 2.75 \\
1999 & 14 & $104,194.8$ & 331.3 & $81,039.7$ & 4.03 \\
2000 & 13 & $158,806.2$ & 846.0 & $110,294.0$ & 4.91 \\
2001 & 13 & $242,242.2$ & $1,513.8$ & $148,148.2$ & 6.74 \\
2002 & 11 & $315,322.4$ & $1,900.5$ & $178,808.2$ & 7.91 \\
2003 & 12 & $392,881.8$ & $2,221.3$ & $210,071.6$ & 8.78 \\
2004 & 13 & $469,145.8$ & $2,031.0$ & $246,336.9$ & 9.40 \\
2005 & 18 & $577,008.7$ & $1,981.4$ & $284,599.1$ & 10.31 \\
\hline
\end{tabular}

Notes: 1/ As of December of each year.

Source: CONSAR, IFS.

Members of the transitional cohort with at least one contribution at the time of the reform can opt for old age retirement benefits under the provisions of the LSS-73. If they become disabled or die, they or their beneficiaries were originally required to buy an annuity from a private insurance sector specialized annuity provider, exactly like members of the new cohort. ${ }^{4}$ Hence in general, benefits are either provided by private sector pension annuity companies or by the IMSS or by the federal government depending on the type of benefits and annuitant being considered (more on this is provided in section III).

The rationale behind mandating the purchase of IV and RT benefits in the private sector while allowing the transitional cohort the option to choose between the old and new old age benefits was related to the fact that, at the time of the reform, old age benefits under the LSS-73 were on average more generous than under the LSS-97, RT benefits were more or less equivalent under the two laws, and IV benefits were on average more generous under the LSS-97 than under the LSS-73. In addition, this would have allowed for the development of a private sector annuity market in Mexico by the time the new entrants to the labor force after 1997 started retiring. These are currently only 37 percent of the IMSS members as reported in the next table.

\footnotetext{
${ }^{3}$ It is worth mentioning that when a pensioner with a PMG dies, IMSS has to buy a survivor annuity for his/her beneficiaries from a private sector annuity provider.

${ }^{4}$ This, as it will be explained later changed in 2002. Notice also that for simplicity we are not discussing the provision of the minimum pension guarantee discussed further in section III.
} 
Table 3: Transitional and New Generations in the Pension System (2004)

\begin{tabular}{lcr}
\hline Workers & Number & Distribution \\
\hline Transitional generation & $7,743,057$ & 63 percent \\
Actual generation & $4,604,993$ & 37 percent \\
Total & $12,348,050$ & 100 percent \\
\hline
\end{tabular}

Source: IMSS

Due to the difference in generosity between the old and new old age benefits, it is expected that all retirees in the transition cohort will elect the on average more generous old age benefits provided for under the LSS-73. In other words, the short-to-medium term prospects for development of the annuity market in Mexico very much depends on the accumulated funds in the IV and RT lines of benefits only.

The next section will analyze the evolution of the pension annuity market as derived from the SAR-97 reform between 1998 and end of 2005. While the term "pension annuities" is used to indicate all annuities derived from the SAR-97 reform, it is often used to indicate the only de facto existing market of IV and RT annuities. The market for old age (retirement) annuities is currently non-existing due to the fact that workers at the time of the reform have the option to elect the (on average) more generous old age benefits under the pre-reform provisions (see more on this issue in section III). Therefore, in the rest of this paper the term "annuity” will be used for IV and RT annuities, unless otherwise indicated.

\section{The Market for Pension AnNuities}

\section{II.A Market Structure and Growth}

With the SAR-97 reform 13 insurance companies were licensed to provide pension annuity benefits in 1997 . At the end of 2005, 11 specialized pension annuity companies were active in the market. Seven of these companies were subsidiaries of foreign companies (F) whilst four companies were part of financial groups (GF). The following table lists the companies operating in the market as of end of 2005 and their market shares in term of written premiums. 
Table 4: Pension Annuity Providers and 2005 Market Shares (Percentage of Market Premium)

\begin{tabular}{lc}
\hline Company & Market share \\
\hline Pensiones BBVA Bancomer, S.A. de C.V., Grupo Financiero BBVA Bancomer 1/ 2/ & 19.7 \\
Pensiones Inbursa, S.A., Grupo Financiero Inbursa 2/ & 17.0 \\
Profuturo GNP Pensiones, S.A. de C.V. & 15.6 \\
Pensiones Banamex, S.A. de C.V., Grupo Financiero Banamex 1/ 2/ & 10.5 \\
Pensiones Banorte Generali, S.A. de C.V., Grupo Financiero Banorte 2/ & 9.0 \\
HSBC Pensiones, SA. 1/ & 6.8 \\
Pensiones Comercial América, S.A. de C.V. & 6.6 \\
Metlife Pensiones México, S.A. 1/ & 6.1 \\
Principal Pensiones, S.A. de C.V. 1/ & 4.4 \\
Allianz Rentas Vitalicias, S.A. 1/ & 2.9 \\
Royal \& SunAlliance Pensiones (México), S.A. de C.V. 1/ & 1.4 \\
\hline Total & 100.0 \\
\hline
\end{tabular}

Note: 1/ Foreign subsidiary; 2/ Belonging to a financial group.

Source: CNSF

The structure of the market changed in the first nine years of operation in two main ways. Initially, the 1997 LGISMS reform stated that insurance companies licensed to practice life insurance were allowed to offer pension annuities for a five years transition period. After that period, those insurance companies would have had to separate annuities operations in specialized pension annuity companies. The 1997 LGISMS also established that, during this transitional period new insurance companies that would like to offer pension annuities would be licensed as specialized insurers. While in 199750 percent of the companies licensed where composite companies, after 2002 only specialized companies were left operating in the market. The rationale for the choice of specialized annuity providers was, on one hand, to avoid the contagion effect from composite life and non-life insurance companies operating annuities, and on the other hand, the implicit government guarantee associated with a benefit provision for which participation was mandated by the federal government. Notwithstanding the political economy argument of the choice, general life insurance companies would have been better placed to hedge the systemic improvements in longevity risk in the annuitant portfolio with the mortality risk in the pure life portfolio.

Another way in which market changed over the year is reflected by the increased importance of subsidiaries (especially foreign) and a decreased importance of financial groups. The following table summarizes the changes in market structured that took place since the SAR-97 reform.

Table 5: Evolution of Market Structure (1997-2005)

\begin{tabular}{lccccccccc}
\hline & $\mathbf{1 9 9 7}$ & $\mathbf{1 9 9 8}$ & $\mathbf{1 9 9 9}$ & $\mathbf{2 0 0 0}$ & $\mathbf{2 0 0 1}$ & $\mathbf{2 0 0 2}$ & $\mathbf{2 0 0 3}$ & $\mathbf{2 0 0 4}$ & $\mathbf{2 0 0 5}$ \\
\hline Foreign Subsidiaries & 4 & 4 & 5 & 5 & 5 & 7 & 6 & 7 & 7 \\
Local Financial Groups & 6 & 5 & 5 & 5 & 5 & 3 & 2 & 2 & 2 \\
Other & 3 & 4 & 4 & 4 & 4 & 3 & 3 & 2 & 2 \\
CR5 (percent) & 85.3 & 77.0 & 73.7 & 71.4 & 72.2 & 72.0 & 72.5 & 72.9 & 71.8 \\
\hline
\end{tabular}

Source: CNSF 
Market concentration has been decreasing but remains fairly high. The participation of the largest five providers in total gross premium written (CR5) has decreased from 85 percent to 72 percent between 1997 and 2001 and remained stable since that year.

The pension annuity market in Mexico is very small. This is due to the fact that the pension reform that created it was conducted only in 1997 and because the Mexican insurance market in general has low penetration and density (1.7 percent of GDP and MXN 1,389 per capita, respectively in 2005). Table 6 reports the evolution of the major business lines of the Mexican insurance market between 1997 and 2005. The gross premium related to the annuity market increased from 3.2 percent to 13.2 percent of total insurance gross premium income between 1997 and 2001 while it decreased again to 3.3 percent in December 2005.

Table 6: Insurance Sector Business Lines Growth (1997-2005)

\begin{tabular}{|c|c|c|c|c|c|c|c|c|c|}
\hline (Percent) & 1997 & 1998 & 1999 & 2000 & 2001 & 2002 & 2003 & 2004 & 2005 \\
\hline Motor & 25.8 & 25.5 & 23.8 & 25 & 24.7 & 24.2 & 26.9 & 24.4 & 25.1 \\
\hline Other P\&C & 25.9 & 20.4 & 18 & 16.8 & 17.4 & 18.5 & 21.4 & 20.3 & 18.9 \\
\hline Life & 35.2 & 31.7 & 36.1 & 34.2 & 33.7 & 39.1 & 36 & 38.9 & 37.9 \\
\hline $\begin{array}{l}\text { Accidents \& } \\
\text { Health }\end{array}$ & 9.8 & 8.9 & 9.4 & 10.6 & 10.9 & 10.9 & 12.9 & 12.7 & 14.8 \\
\hline Pensions & 3.2 & 13.5 & 12.7 & 13.2 & 13.2 & 7.3 & 2.7 & 3.7 & 3.3 \\
\hline $\begin{array}{l}\text { Total GPI } \\
\text { (MXN mln) } \\
1 /\end{array}$ & 78,639 & 94,811 & 101,001 & 110,320 & 125,699 & 140,928 & 128,063 & 142,640 & 138,377 \\
\hline $\begin{array}{l}\text { GPI/GDP } \\
\text { (percent) }\end{array}$ & 1.3 & 1.5 & 1.6 & 1.6 & 1.8 & 2.0 & 1.8 & 1.9 & 1.7 \\
\hline $\begin{array}{l}\text { GPI/Pop. } \\
\text { (MXN) }\end{array}$ & 839 & 999 & 1,051 & 1,133 & 1,273 & 1,408 & 1,263 & 1,389 & 1,331 \\
\hline
\end{tabular}

Notes: 1/ Real 2005 pesos..

Source: CNSF, IFS, WDI.

Table 7 summarizes the growth of the pension annuity market in terms of key variables between 1997 and 2005. The number of annuitants for the benefits of IV and RT increased every year between 1997 and 2002. Afterwards, figures decreased sharply. The number of eligible annuitants increased from 6,068 in 1997 to 30,778 in 2001. The number of individuals who had bought a pension annuity from private sector providers increased from 4,410 in 1997 to 30,824 in 2001. In the ensuing years the number of eligible individuals and actual annuitants decreased to around 7,900 in 2005.

The same pattern can be observed in the value of pension annuity premiums with the exception of 2004 when a spike in premiums written can be observed. ${ }^{5}$ Between 1997 and 2001, gross written premium increased from MXN 2,522 million (annualized) to MXN 16,641 million. In the ensuing months it decreased to reach MXN 4,504 million in

\footnotetext{
${ }^{5}$ That was due to an amendment to the LSS-97 that increased the pension amount to those pensioners satisfying the legal requirements established by that amendment. This implied a transfer of almost $\$ 1,700$ million MXN of single premium to the annuities companies.
} 
2005. The 2004 increase in premiums was due to an increase in IV and RT pension annuities approved by the congress in that year that required retroactive payments for insured individuals as of March 2004. Within the period between 1997 and 2005 the share of premiums for IV benefits decreased from 96 percent of total premiums in 1997 to 85 percent in 2005.

Table 7: Pension Annuity Market Growth (1997-2005)

\begin{tabular}{|c|c|c|c|c|c|c|c|c|c|}
\hline & 1997 & 1998 & 1999 & 2000 & 2001 & 2002 & 2003 & 2004 & 2005 \\
\hline Eligible Insured & 6,068 & 23,905 & 24,782 & 27,384 & 30,778 & 14,879 & 5,998 & 6,365 & 7,917 \\
\hline Annuitants & 4,410 & 23,457 & 24,599 & 27,188 & 30,824 & 15,798 & 6,153 & 6,187 & 7,927 \\
\hline $\begin{array}{l}\text { GPI (MXN mln.) } \\
1 /\end{array}$ & 2,522 & 12,913 & 13,389 & 14,529 & 16,641 & 10,261 & 3,497 & 5,225 & 4,504 \\
\hline$o / w I V$ (percent) & 96 & 90 & 87 & 86 & 86 & 86 & 86 & 85 & 85 \\
\hline GPI/GDP (percent) & 0.08 & 0.33 & 0.29 & 0.26 & 0.28 & 0.16 & 0.05 & 0.07 & 0.05 \\
\hline GPI/Pop. (MXN) & 26.9 & 139.0 & 139.3 & 149.0 & 168.3 & 102.4 & 34.4 & 50.8 & 43.6 \\
\hline
\end{tabular}

Notes: 1/ Real 2005 Pesos.

Source: CNSF, IFS, WDI.

Pension annuity market penetration increased from 0.1 percent to 0.3 percent of GDP between 1997 and 2001 while afterwards it decreased until reaching five basis points in December 2005. Again a similar pattern can be observed in terms of market density.

Section III of this paper provides a detailed discussion of the factors behind the mentioned major change in the trends in the pension annuity market after 2001/2002.

\section{II.B Pension Annuity Products, Pricing, and Competition}

Pension annuities stemming from the 1997 reform are all immediate premium level annuities indexed to inflation (CNSF 2006g). The products have two components: (1) an annuity for retirement, unemployment at old age, disability, incapacity, worker's compensation, orphans, widows and widowers; and (2) a survivor benefit for eventual beneficiaries existing when the right to a pension annuity is acquired. In calculating premiums, pension annuity companies calculate separately the premium related to the annuity and the premium related to the survivor benefit. The calculation of the survivor benefit considers the death conditional probability of the pensioner.

Two sets of gender specific mortality tables are used for insured members that are disabled or not disabled and a unique technical rate of 3.5 percent real has to be used. For male and female disabled pensioners (IV benefits), the two mortality tables used are the $\mathrm{EMSSI}_{\mathrm{M}^{-}}-97$ and the $\mathrm{EMSSI}_{\mathrm{H}^{-}}-97$, respectively. These tables were developed by the IMSS. For non-disabled male and female pensioners the mortality tables used are the EMSSA $_{M^{-}}-97$ and EMSSA $_{H^{-}} 97$, respectively. These tables were prepared by the CNSF on the basis of information provided by the Population National College (CONAPO). These are gender specific dynamic tables approved by the special committee formed 
under Art 81 of the LSAR for this purpose (CNSF 2006). The methodology used for the creation of these tables was revised by the Mexican College of Actuaries (CONAC). ${ }^{6}$

Other factors influence the pricing of annuities. Since annuities are indexed every February to the inflation of the previous fiscal year a system of factors was developed to consider that: (1) it is possible the month of February falls between the date in which the insured individual acquires pension rights and the date when the IMSS declares the insured individual disabled; (2) pension benefits can be granted at any time during the month and companies need to credit the inflation every month. In addition, two types of mark ups are added to the premium: (1) a 2 percent mark-up (which is accumulated in the contingency reserve discussed in section II.C) is added to the premium as an extra buffer to compensate for possible statistical deviations in the mortality table; and (2) a 1 percent mark-up is added to finance acquisition costs incurred during the sale of the annuity and administration costs incurred during the payment of the annuity.

Since demographic and technical parameters used for pricing annuities are fixed by regulations, any new annuitant has access to the same IV and RT annuity irrespectively of the provider elected. This is ensured by a requirement for all companies to use a single pricing system (known as "SUC"7) for calculating immediate premiums. This is nothing more than a piece of software that captures the relevant data of the individual and his/her beneficiaries and uses all pricing parameters prescribed by regulations. The rationale behind the single methodology for pricing annuities is related to the fact that on the one hand, the LSS-97 establishes defined benefit for IV and RT pensions, and on the other hand, it grants the right to pensioners to choose an annuity company. In addition, this methodology strives at eliminating unfair commercial practices towards retirees and towards the IMSS that ultimately pays premiums through its accumulated IV reserves.

In order to compete for clients, companies offer additional benefits to the basic IV and RT annuities. In the case of life insurance benefits, the annuities companies have to purchase additional benefits from other insurance companies authorized to operate life insurance business. Notice that the offer of additional benefits does not affect the price offered to the insured individual for the basic pension benefit. In other words, companies absorb all costs for additional benefits and finance them through the spread between the technical rate and the expected return on assets.

These additional benefits are tightly regulated in order to ensure that they are in line with the solvency profile of the company, and to avoid undue commercial practices. Additional benefits need to be registered in the CNSF before being offered to the pensioners. The additional benefits registered at the CNSF are posted on its website. They can only fall in one of two categories: 1) additional economic benefits constituting increments on the basic pension; and 2) life insurance products bought for the pensioner or their beneficiaries. In general, additional benefits can be offered during the duration of the basic pension benefit. In the case of additional economic benefits, pension annuity companies are required to constitute the corresponding reserves ${ }^{8}$ considering a technical interest rate of 1 percent in real terms. In addition, life insurance benefits have to be

\footnotetext{
${ }^{6}$ Colegio Nacional de Actuarios de México (CONAC)

${ }^{7}$ Sistema Único de Cotización (SUC).

${ }^{8}$ More precisely, this is the mathematical or net premium reserve as it will be explained in section II.
} 
purchased from other insurance companies paying a single premium, and this amount is registered as acquisition cost of the annuity company. ${ }^{9}$ It is important to point out that the same mortality table used for basic benefits is used for additional economic benefits (CNSF 2006h).

The regulatory framework for pricing of pension annuities in Mexico has the potential for making the basic annuity offered an unbalanced product. This is a risk for both providers and annuitants.

For providers there is a concrete possibility that technical profit margins are quickly eroded if technical rates are not adjusted rapidly. For instance, the long term real interest rate in the case of $10 \mathrm{yr}$ Udibonos $^{10}$ has decreased from around 7.14 percent in October 1999 to 4.30 percent in December 2005 and has been increasing gradually to reach a level of 5.09 percent in June $2006^{11}$; in the case of 20 and 30 yr PICs ${ }^{12}$ the long term real interest rates have passed from 6.14 and 6.12 in October 2001 to 5.96 and 5.92 in November 2002 respectively and in the case of 20 and $30{\mathrm{yr} C B I C s^{13}}^{13}$ the long term real interest rates decreased from 6.16 and 6.21 percent in January 2003 to 4.59 and 4.68 percent in December 2005 in that order; while the technical rate of 3.5 percent real has not been modified (see section II.E).

The mortality tables used are experimental tables based on population averages and annuity companies would need to develop their own annuitant mortality tables when sufficient mortality experience is accumulated. This is especially urgent since pension policy changes introduced in 2002 have altered the demographic assumptions at the basis of the pricing framework adopted in 1997 so that the IV annuitant pool is quickly degenerating (see section III). Since 2000 the CNSF has prepared some studies in order to analyze the adequacy of the experimental market tables. However since 2002, the trends of the mortality have changed and it is necessary to collect statistical market information for at least five years to propose a new table.

\footnotetext{
${ }^{9}$ In the case of life insurance benefits the corresponding reserves are constituted by the life insurance companies (sellers).

${ }^{10}$ Pension annuity companies have large positions of government bonds known as UDIBONOS (Bonos De Desarrollo Del Gobierno Federal Denominados En Unidades De Inversión), PICs (Pagarés de Indemnización Carretera con aval del Gobierno Federal) and CBICs (Certificados Bursátiles de Indemnización Carretera con aval del Gobierno Federal) that have maturities between seven and 28 years. ${ }^{11}$ For 10 year UDIBONOS, the auctions average result reached the lowest real annual interest rate level (3.89 percent) in October 2003. Source: Banxico.

12 The highway indemnification promissory notes, know as PICs were issued until December 2002, as part of the support program for the rescue of the highways under Concession. These notes were endorsed by the federal government. The annual interest rates correspond to the auctions results. Source: Banxico and Banobras.

${ }^{13}$ CBICs were issued since January 2003. The interest rate considered is the CBIC real annual interest rate of the monthly auctions results. Source: Banxico and Banobras.
} 


\section{Box 1: Chilean Annuities Are Good Value Products Even With Price Deregulation}

Contrary to the Mexico case, pricing of Chilean pension annuities is not regulated. Consequently, prices varies over time and across individuals. In Chile there is evidence that annuities with longer expected durations have lower money's worth ratios than annuities with shorter expected durations, and that larger premiums buy annuities that on average are of better value than smaller ones. This is consistent with the view that insurers are concerned with the higher reinvestment and mortality risks presented by long durations and, in the case of size, the effect of fixed expense loadings. Also, nearly half of the variation in individual money's worth ratios is not explained by individual characteristics. The wide spread between the highest and the lowest annuity is intriguing, and is specially wide for lower premium annuities, indicating that market search may be inefficient among lower income retirees. Finally, annuitants with the same characteristics such as age, premium, and gender frequently receive different annuities.

The high variability in money's worth ratios (especially at low premia) has led to the conclusion that brokers and sales agents can unduly influence the selection of products. This led to the introduction of a new electronic quotation system designed to improve transparency in the market for retirement products, and ensure that retirees effectively obtain the best quotes. This is an innovative and promising reform, the results of which should be closely monitored by regulators in other countries. The recent introduction of caps on broker commissions proved controversial but is another experience that merits close monitoring as well.

The variability in annuity prices in Chile should not suggest that prices should not be de-regulated in Mexico. Despite price variation, Chilean annuitants have generally received a good value for their premia so far, as indicated by average money's worth ratios on their indexed annuities around $1.04-1.08$ in recent years. These are significantly higher than the unitary value considered as an actuarially fair annuity.

Average money's worth ratios in Chile have been high by international comparison. In most other countries money's worth ratios range from 0.9 to 1 for nominal annuities, and from 0.8 to 0.85 for indexed annuities, in the few countries that offer inflation protection, such as the UK. The higher money's worth ratios of indexed annuities in Chile are in part due to the availability of a large supply of financial assets indexed to prices, including higher yield assets such as mortgage, corporate and infrastructure bonds. This has allowed annuity providers to hedge inflation risk efficiently while also extracting higher real returns and sharing them with annuitants.

Such high ratios are considered the result of a very competitive environment but likely to be unsustainable in the long run. Despite the fact that ratios will need adjusting in the future, they are likely to remain competitive if compared internationally.

Finally, the fixed pricing rules, determined by the legal constrains mentioned previously, may expose annuitants to undesired "provider risk" as the solvency situation of any given company is not reflected in the price of the annuity it offers. ${ }^{14}$ In a low long term real interest rate environment and without the timely adjustment of the regulatory technical

\footnotetext{
${ }^{14}$ Clearly this observation should be weighted by the fact that product pricing is the result of complex interactions between operational objectives of a company, such as profit, market share and market positioning, and security objectives, such as reinsurance, investment philosophy and reserving (when not regulated). When companies are free to charge prices on the basis of sound rates, these prices are usually more dynamic and their relationship to sound rates may vary from time to time with the state of the market and with the expectations of management and shareholders. In other words, prices may not need to always reflect the solvency situation (although they are expected to be highly correlated with it) of a company.
} 
rate, the inability of companies to establish sound premium rates ${ }^{15}$ may expose themselves and annuitants to undesirable level of risk.

For annuitants, fixed technical parameters are no guarantee of good value products in an environment of changing circumstances. ${ }^{16}$ The Chilean experience, reported in the Box 1 , would suggest that annuitants can receive a good value for their premia in a highly competitive and efficient market even if technical parameters are deregulated.

\section{II.C Evolution of Liabilities}

Mexican pension annuity providers need to form a variety of technical provisions ${ }^{17}$ for both pension and additional benefits. ${ }^{18}$ Due to the fact that pension annuities are all immediate premium annuities, the largest provision is obviously the net mathematical (or premium) reserve (NPR) (reserva de riesgos en curso). ${ }^{19}$ This is formed with the immediate premium of IV and RT benefits and it backs the provision of annuities considering a technical rate of 3.5 percent in real terms. Companies have also to constitute the premium reserve corresponding to additional economic benefits in which case the use of a technical rate of 1 percent in real terms is required. The NPR reserve is gradually "earned" when benefits are paid and it has always represented between 95 percent and 97 percent of total reserves in the 1997 - 2005 period. The contingency reserve (reserva de contingencia o de previsión) is used to cover possible statistical deviations in the expected loss ratio and it is formed with 2 percent of the mathematical reserves for basic pension and additional benefits. ${ }^{20}$ The special mathematical reserve for basic pension benefits (reserve matemática especial) is used to cover possible systemic improvements in the longevity of the annuitant pool for non disabled pensioners. The reserve for fluctuation in investments (reserva para las fluctuaciones en inversiones) is used to cover for unexpected fluctuations in the return on the investment of the reserves. This reserve is constituted by a portion of the excess investment rate of return of the market portfolio over the technical interest rate (3.5 percent real). Finally, the loss reserve (reserva para obligaciones pendientes de cumplir), is used for liabilities that providers have with their pensioners. The next table reports the behavior of the different types of reserves just mentioned within the period $1997-2005$.

\footnotetext{
${ }^{15}$ Sound rates are based on sound insurance principles and have regard to the portfolio being written and the changing social, economic, legislative and technological environment.

${ }^{16}$ Which in the case of mexico is simply determined by the defined benefit nature of the IV and RT pensions.

17 The methods for the formation of such reserves are detailed in SHCP (1997).

18 The share of technical provisions for additional benefits was only 2 percent in 2005.

${ }^{19}$ The NPR is the long plan equivalent of the unearned premium reserve (UPR) for P\&C insurers.

${ }^{20}$ Annuity premiums include a 3 percent of surcharge composed by 2 percent for mortality deviations and 1 percent for administrative and acquisition cost.
} 
Table 8: Evolution of Separate Technical Provisions (1997-2005, MXN mln.)

\begin{tabular}{lrrrrrrrrr}
\hline $\mathbf{1 /}$ & $\mathbf{1 9 9 7}$ & $\mathbf{1 9 9 8}$ & $\mathbf{1 9 9 9}$ & \multicolumn{1}{c}{$\mathbf{2 0 0 0}$} & $\mathbf{2 0 0 1}$ & $\mathbf{2 0 0 2}$ & $\mathbf{2 0 0 3}$ & $\mathbf{2 0 0 4}$ & $\mathbf{2 0 0 5}$ \\
\hline NPR & $2,332.4$ & $14,774.8$ & $27,417.3$ & $40,728.7$ & $55,791.0$ & $63,875.1$ & $65,429.0$ & $68,592.6$ & $70,624.7$ \\
Pending NPR & 51.5 & 37.2 & 55.3 & 60.8 & 43.2 & 10.6 & 7.20 & 10.8 & 7.5 \\
Contingency & 46.7 & 295.0 & 548.3 & 814.5 & $1,115.0$ & $1,277.0$ & $1,308.0$ & $1,371.0$ & $1,412.0$ \\
Special Mat. & 0.3 & 9.6 & 32.7 & 82.1 & 139.5 & 226.2 & 315.5 & 445.0 & 574.4 \\
Inv. Fluct. & 1.8 & 33.7 & 156.2 & 234.1 & 333.6 & 628.0 & 744.9 & 747.1 & 817.8 \\
Loss Reserves. & 7.4 & 9.7 & 15.2 & 33.8 & 70.6 & 97.1 & 133.2 & 167.5 & 203.6 \\
\hline NPR/Total (\%) & 96 & 97 & 97 & 97 & 97 & 97 & 96 & 96 & 96 \\
\hline
\end{tabular}

Notes: 1/ Real 2005 Pesos.

Source: CNSF

Technical provisions also display a similar pattern of high growth until 2001 and much lower growth afterwards reported before for premiums in section II.A. Between 1997 and 2001 technical provisions increased from MXN 2,440 million to MXN 57,493 million while reaching only MXN 73,640.41 in December 2005 as shown in Figure 1.

Figure 1: Evolution of Total Technical Provisions (Real 2005 MXN mln.)

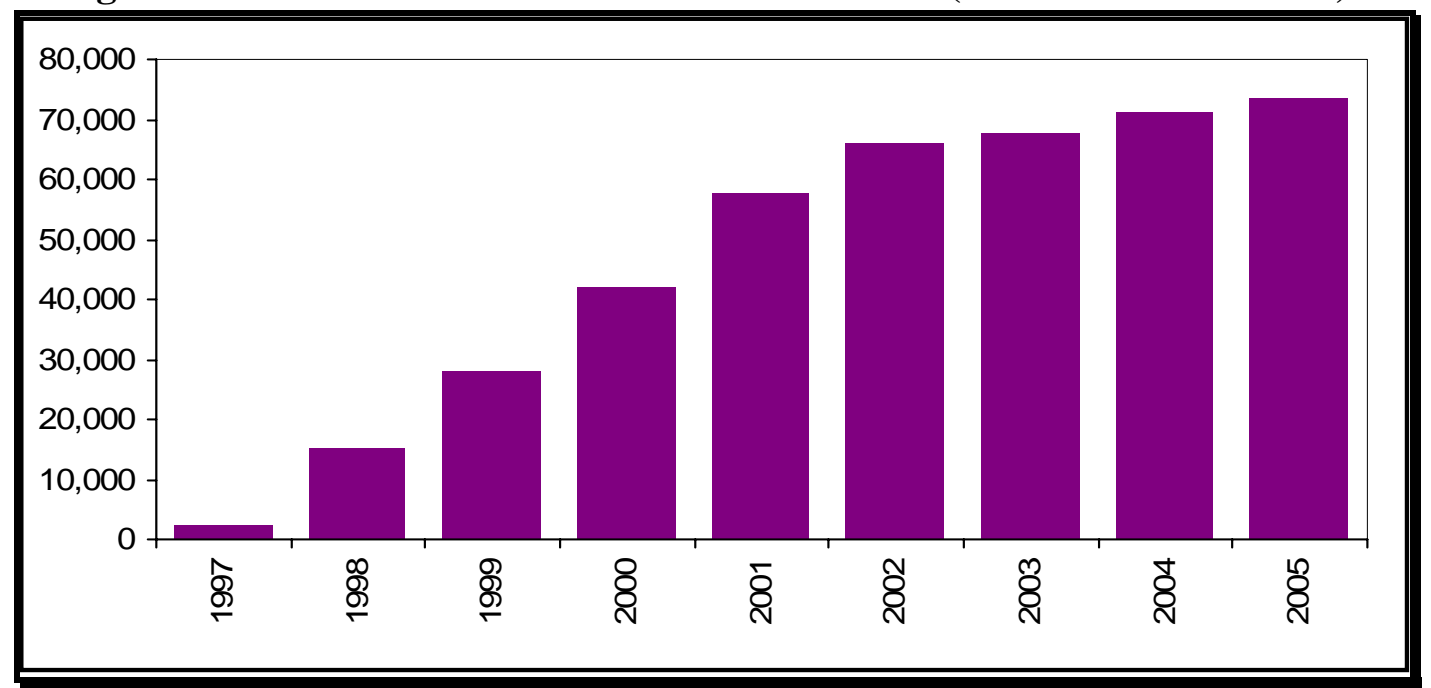

Source: CNSF

A major change was introduced in 2002 in the regulation with respect to the valuation of technical provisions of life, accident and illness, and P\&C lines of businesses by amending Article 47 of the Insurance Law (LGISMS). In essence, the new rules state that the valuation of technical provisions has to be conducted on the basis of actuarial standards requiring an actuarial valuation of future risks. ${ }^{21}$ In the case of annuities, it was

\footnotetext{
${ }^{21}$ Regarding the unearned premium reserve for all lines of business (excepting annuities) the old methodology for the calculation and valuation of the technical reserves was based on premiums. Insurance companies that followed this regulation scheme could face actuarial insufficiency of technical reserves, because reserves relayed only on the adequacy of premiums. Consequently, if the risk premium was insufficient to pay claims, the technical reserve would also be insufficient. In addition, in high competitive
} 
established in 1997 that the valuation of technical provisions should be made on the basis of the actuarial methodology issued by the Ministry of Finance. ${ }^{22}$ For pension annuity companies that underwrite inflation indexed products, the methodology applicable to the formation of the net premium reserve includes additional provisions aimed at avoiding eventual revaluation of the reserve due to changes in inflation. ${ }^{23}$ In all cases, since 2004, the valuation of the technical provision must be reviewed and signed by an actuary that must be certified by the National College of Actuaries (CONAC) or approved by the CNSF. Consequently, standards of actuarial practices where developed by the CONAC, and one of them indicates the principles that actuaries must apply to calculate the technical provisions. These standards were published by the CNSF in Circulares S10.1.8 and F-6.6.4.

\section{II.D Evolution of Assets and Investment}

Total assets in the pension annuity market follow closely the behavior of liabilities given the long term nature of the pension annuity business. For instance, average total assets in the last nine years have been 90 percent financed by liabilities and only 10 percent by paid up capital. The liability share is clearly increasing with time until the

markets some insurers would lower premiums in order to retain costumers, making it difficult to control if premiums are exactly associated to the risk assumed by the insurance companies. (Premium manipulation does not relate to the annuity market as pricing parameters are fixed by regulation. The observation made relates to the general rationale behind the choice to change accumulation and valuation methodologies for the whole insurance industry). The new rules (CNSF 2003, 2003a, 2003b, 2004, and 2005) containing specific instructions for the actuarial valuation of the NPR were implemented in 2004. All companies are now required, for each line of business, to file with the CNSF an actuarial methodology for the valuation of the adequacy of reserves. Regulations also include a minimum requirement level for the technical provisions. In the case of claims reserves, companies are also required to use an actuarial method for the estimation of reported claims without a precise valuation of the loss (CNSF 2003c). The methodology must estimate the technical provisions as the expected value of future claims derived from all the policies in force from the valuation date until the expiration date of every policy. The methodology must specify a projection model of future claims, based on the trends of claims observed by the company in the previous years. In case a company does not have adequate statistical data, it must file a temporary methodology also approved by the CNSF who also has the power to assign a methodology for as long the company files one considered as adequate.

22 This methodology is detailed in SHCP (2000).

${ }^{23}$ Notice that liabilities are inflation indexed by regulation. Hence, the methodology for forming the NPR needs containing an element that neutralizes the effect of the revaluation of the reserve due to changes in inflation. The following formula shows gives the value of the NPR reserve at the end of every month:

$$
V_{m}=\left({ }_{m-1} V+\frac{1}{2} G P I_{m}-\frac{1}{2} C_{m}\right)\left(1+\Delta I N P C_{m}\right)(1+i)^{1 / 12}
$$

where $V_{m}$ is the NPR reserve at the end of month $m ;{ }_{m-1} V$ is the NPR reserve at the end of the previous month; $G P I_{m}$ is the gross premium income of the policies issued during the month $m$; $C$ are the claims paid during the month $m ; \Delta I N P C_{m}$ is the change in the price index during the month $m$; and $i$ is the technical rate of 3.5 percent real that companies need to use in pricing their product. The difference $\left(V_{m}-{ }_{m-1} V\right)=R M A_{m}$ is the monthly minimum accumulation rate (rendimiento mínimo acreditable) that companies need to use to form the UPR reserve. Notice that the use of $1 / 2$ for premiums and claims implies that these are uniformly distributed within the month. 
annuitant population matures. Since assets closely follow the pattern of liabilities, assets too grew rapidly until 2001 and less rapidly since then due to the decreased income after that year as previously reported for premiums and technical provisions. In the first five years since the reform, total assets reached MXN 60,000 million while in the last four years they increase about only MXN 21,000 million.

Figure 2 shows the evolution of total assets and its sources of financing: liabilities and capital. Notice that the drastic increase in capital registered in 2003 was due the decision of one company to transfer to capital excess resources and results in participation in subsidiaries. The same company in 2004 registered another increment in capital as a result of its participation in subsidiaries. In 2005, the same company disinvested around MXN 7 billion. Due to the fact that capital excess resources were stocks not listed on the Mexican stock exchange market, there was no effect on the solvency of the annuity market.

Figure 2: Evolution and Financing of Total Assets (Real 2005 MXN mln.)

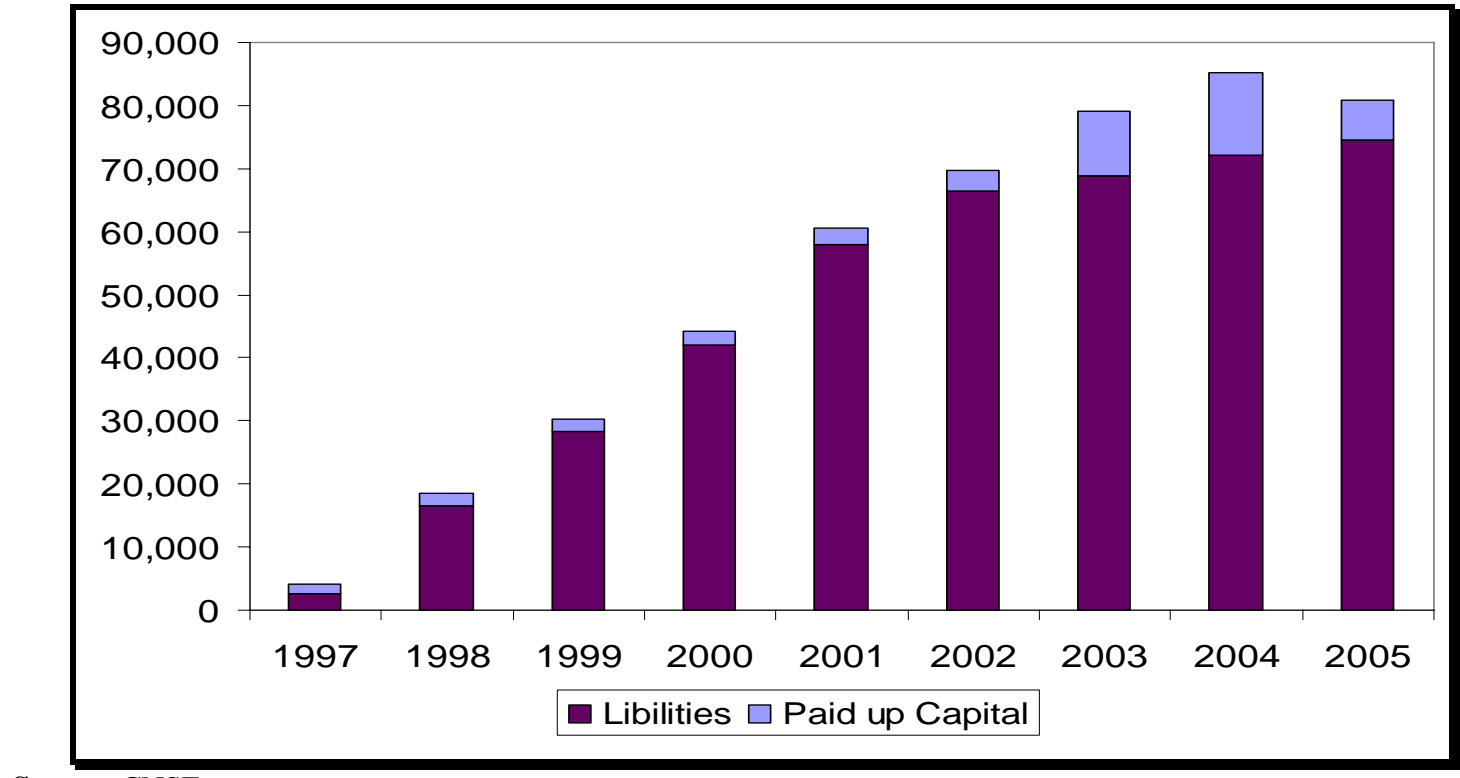

Source: CNSF.

Investment of technical provisions of pension annuity companies is subject to the same rules applicable to other insurance companies in Mexico. The regulatory framework for investments of technical provisions is contained in the RIRT (CNSF 2000) and Circulares S-11.1 to S-11.6, which in turn, expand on the general provisions contained in Articles 56, 57, 58, 59, 81 (Cap II, III and IV), 82 (Cap XIV), 91 and 92 of the Insurance Law (LGISMS). Such framework regulates the formation and operations of the investment committee, the list of assets that are admitted in representation (to cover) liabilities, rates for private companies' values, currency and duration matching, custody requirements, investment administration and investment limits per issuer or security type. In what follows, we focus on admitted assets, investment limits, liquidity requirements, 
custody and investment administration, inflation and duration matching rules, and credit risk limits.

Admitted assets —According to the RIRT, assets admitted in representation of liabilities must belong to the following list (CNSF 2006a):

- $\quad$ Securities registered in the SIC of the Mexican Stock Exchange.

- Investments in equity and fixed income mutual funds with portfolios that include foreign securities issued by Central Banks or any other level of government by countries of the European Union, or countries belonging to the Technical Committee of the International Organization of Securities Commissions (IOSCO), as well as securities that are registered, authorized or regulated for general public sale by the Banking and Securities National Commission (CNBV) or the equivalent organizations of the above mentioned countries.

- $\quad$ Securities denominated in national currency issued by international financial institutions in which Mexico is a member.

- $\quad$ Private equity investment funds in Equity Investment Societies (Sociedades de Inversión de Capitales, SINCAS), as well as in trusts whose purpose is to capitalize firms.

It is important to notice that investment rules also include the following requirements:

Investment limits - Investment limits comprise both limits, by type of instrument and by issuer, as summarized in the next two tables.

Table 9: Investment Limits by Type of Security for Technical Provisions Investment type

(1) Papers issued or backed by the federal government Limit (in percent)

(2) Papers issued or backed by credit institutions or international financial bodies

(3) Papers issued by SINCAS

(4) Papers issued or backed by institutions different from those in (1),

(2), and (3)

(5) Papers issued or backed by institutions different from those in (1),

(2), and (3) exchange at the Mexican Stock Exchange

(6) Discount and rediscount operations

5

(7) Credit with pledge bonds or papers guarantee

(8) Credit with mortgage guarantee

(9) Real state properties 
Table 10: Investment Limits by Type of Issuer for Technical Provisions

Investment type

(1) Federal government Limit (in percent)

(2) Banks or international financial bodies

100.0

(3) SINCAS

18.0

(4) Institutions different from those in (1), (2), and (3)

(5) Groups and institutions in the same economic sector (shares) 1/ 2/

7.0

(6) Financial institution (shares) 1/

10.0

(7) Stock and papers issued inter-related groups

5.0

(8) Foreign securities belonging to investment funds

18.0

(9) Securities registered in the SIC (Sistema Internacional de

1.0

Cotizaciones) of the Mexican Stock Exchange.

Notes: 1/ Constitute standard risk for mutual insurance companies; 2/ For manufacturing, this limit can reach up to 20 percent.

Source: RIRT and CNSF (2006b).

Liquidity requirements _ In order for investment portfolios to maintain an adequate degree of liquidity, companies must cover short term technical reserves with equivalent assets. The determination of these short term obligations is obtained by assigning a percentage short term requirement to each type of reserve and the total must be covered with investments with maturities of a year or less or equity shares classified as highly traded. The shares of reserves that have to be invested in liquid instruments used to be based on prudent limits that varied from 100 percent for the loss reserve to 6 percent for the NPR, the contingency and the special mathematical reserves. Starting with 2006, liquidity requirements must be calculated according to the calculation derived from the asset—matching analysis for the pensions.

In addition, liquidity requirements for life operation must be calculated for each type of life insurance policies issued by companies and more specifically taking into account the proportion of technical provisions generated from short term insurance policies relatively to the proportion of technical provisions generated from long term life insurance.

Custody and investment administration—All titles and securities referred in the regulations and issued in the country must be administered by credit institutions or securities firms, and must be kept in custody by depository institutions for securities. In the case of investments in foreign currency operated outside the country, only Mexican Financial Entities or its subsidiaries may act as intermediaries which may use, as custodians, the authorized depositary entities in the applicable jurisdiction in the foreign country.

Matching rules_Solvency Margin Rules (Reglas para el Capital Mínimo de Garantía de las Instituciones de Seguros) were amended to include the matching of assets and liabilities for life insurance starting in January, 2006. For pension annuity companies these rules were established in 2000 and include duration, inflation and currency matching of liabilities and assets admitted in their representation. In general terms, for the annuity companies, obligations must be covered by assets same currency (indexed to the inflation) although there are specific exceptions: 
- $\quad$ Before 1999 investment rules prescribed the investment of technical reserve only in inflation indexed instruments. After 1999, companies were allowed to invest in nominal instruments with yield higher than inflation as long as they acquire derivative products to cover the inflation risk. After the year 2000 companies were allowed to invest up to 10 percent of technical reserves in foreign currency instruments issued or guaranteed by the federal government.

- $\quad$ Institutions may cover obligations in foreign currency with their equivalent in local currency by means of acquiring derivative products exclusively for covering exchange rate risk with authorized intermediaries and recognized markets by the Central Bank.

Credit risk rules _ In order to minimize the risk, all private debt securities as well as titles in investment funds used by insurance companies to cover technical reserves must have a minimum acceptable rating determined by a rating agency approved by the Banking and Securities National Commission (CNBV).

The following table reports the evolution of investment of technical reserves. Most of the provisions are invested in government bonds. Companies are required to fully hedge inflation and interest rate risk and only a very small currency mismatch is allowed by regulation between assets and liabilities. Since private sector issuers of inflation linked long term bonds are essentially non existent, this is done by purchasing inflation linked instruments with long maturities that are mostly issued by the federal government.

Table 11: Investment of Technical Provisions (1997-2005)

\begin{tabular}{lrrrrrrrrr}
\hline \multicolumn{1}{c}{ (percent) } & $\mathbf{1 9 9 7}$ & $\mathbf{1 9 9 8}$ & $\mathbf{1 9 9 9}$ & $\mathbf{2 0 0 0}$ & $\mathbf{2 0 0 1}$ & $\mathbf{2 0 0 2}$ & $\mathbf{2 0 0 3}$ & $\mathbf{2 0 0 4}$ & $\mathbf{2 0 0 5}$ \\
\hline Other Inv. & 1.5 & 1.5 & 4.7 & 4.9 & 6.8 & 7.8 & 10.6 & 15.3 & 11.8 \\
Private Sec. & 20.0 & 16.3 & 10.4 & 14.4 & 10.4 & 11.6 & 15.7 & 16.2 & 11.9 \\
Government Sec. & 78.5 & 82.2 & 84.9 & 80.7 & 82.8 & 80.6 & 73.7 & 68.5 & 76.3 \\
Total (MXN mln.) /1 & 3,602 & 16,191 & 29,713 & 43,743 & 60,039 & 69,061 & 78,112 & 84,112 & 79,852 \\
\hline
\end{tabular}

Notes: 1/ constant prices as of Dec 2005.

Source: CNSF

The following table reports instead how the investment of technical reserves has shifted over time from nominal and foreign assets to real and domestic assets; thus considerably reducing exposure to inflation and currency risk.

Table 12: Inflation and Currency Risk in Technical Provisions (1997-2005)

\begin{tabular}{lrrrrrrrrr}
\hline \multicolumn{1}{c}{ (percent) } & $\mathbf{1 9 9 7}$ & $\mathbf{1 9 9 8}$ & $\mathbf{1 9 9 9}$ & $\mathbf{2 0 0 0}$ & $\mathbf{2 0 0 1}$ & $\mathbf{2 0 0 2}$ & $\mathbf{2 0 0 3}$ & $\mathbf{2 0 0 4}$ & $\mathbf{2 0 0 5}$ \\
\hline Local nominal & 36.1 & 40.7 & 14.0 & 4.0 & 5.1 & 4.8 & 0.2 & 0.5 & 0.4 \\
Foreign nominal & 3.9 & 1.3 & 1.6 & 2.6 & 2.4 & 2.3 & 2.2 & 3.6 & 0.8 \\
Local real & 60.0 & 58.0 & 84.4 & 93.1 & 92.2 & 92.6 & 97.4 & 94.2 & 91.3 \\
Local and foreign nominal 1/ & 0.0 & 0.0 & 0.0 & 0.4 & 0.3 & 0.3 & 0.3 & 1.7 & 7.6 \\
\hline
\end{tabular}

Notes: $1 /$ with inflation rate guaranteed.

Source: CNSF 
For accounting purposes investment portfolios can be classified in two types: (1) for sale; and (2) to hold until maturity. The first type of portfolio is used to finance operations and short term liabilities such as acquisition or operation costs and payment of benefits. Due to the short term nature of this portfolio assets are marked to market. The second type of portfolio is used to back longer term liabilities, the valuation of which is based on a constant discount rate. It is natural to classify in these circumstances all reserves in at least the UPR as held to maturity. Due to the nature of this portfolio, assets are valued at maturity. On average, 90 percent of the portfolio of pension annuity companies is classified as "held to maturity." Always for accounting purposes, liabilities regarding basic benefits are valued at the fixed technical interest rate defined in regulations which is currently 3.5 percent real.

However, in economic terms companies are required to set up asset liability management policies and hedge interest rate risk by matching assets with liabilities by the use of duration metrics. It was not possible to collect information on the evolution of the average duration mismatch between assets and liabilities. However, it was possible to collect information about the evolution of the average maturity of government and private sector bonds reported in the following two tables:

Table 13: Average Maturity of Government Bond Portfolio (Years)

\begin{tabular}{lrrrrrrrrr}
\hline & $\mathbf{1 9 9 7}$ & $\mathbf{1 9 9 8}$ & $\mathbf{1 9 9 9}$ & $\mathbf{2 0 0 0}$ & $\mathbf{2 0 0 1}$ & $\mathbf{2 0 0 2}$ & $\mathbf{2 0 0 3}$ & $\mathbf{2 0 0 4}$ & $\mathbf{2 0 0 5}$ \\
\hline $\mathrm{y}<=1$ & 0.00 & 0.00 & 0.38 & 0.39 & 0.52 & 0.23 & 0.18 & 0.27 & 0.26 \\
$1<\mathrm{y}<=5$ & 3.42 & 3.09 & 2.96 & 2.43 & 2.24 & 3.83 & 3.03 & 3.32 & 2.48 \\
$5<\mathrm{y}<=10$ & 8.71 & 7.11 & 8.01 & 7.73 & 6.78 & 8.29 & 7.29 & 7.36 & 6.73 \\
$10<\mathrm{y}<=15$ & 12.36 & 12.30 & 12.15 & 11.63 & 10.63 & 13.72 & 13.18 & 12.74 & 12.34 \\
$\mathrm{y}>15$ & 31.88 & 30.76 & 29.74 & 28.86 & 26.23 & 25.77 & 25.30 & 24.44 & 23.90 \\
\hline Total Government & 6.14 & 7.51 & 6.73 & 13.07 & 14.71 & 16.36 & 14.76 & 14.88 & 14.53 \\
Total bond portfolio & 5.80 & 7.30 & 6.50 & 11.80 & 13.70 & 15.00 & 13.40 & 13.60 & 14.20 \\
\hline
\end{tabular}

Source: CNSF

Table 14: Average Maturity of Private Sector Bond Portfolio (Years)

\begin{tabular}{lrrrrrrrrr}
\hline & $\mathbf{1 9 9 7}$ & $\mathbf{1 9 9 8}$ & $\mathbf{1 9 9 9}$ & $\mathbf{2 0 0 0}$ & $\mathbf{2 0 0 1}$ & $\mathbf{2 0 0 2}$ & $\mathbf{2 0 0 3}$ & $\mathbf{2 0 0 4}$ & $\mathbf{2 0 0 5}$ \\
\hline $\mathrm{y}<=1$ & 0.00 & 0.00 & 0.11 & 0.14 & 0.12 & 0.46 & 0.36 & 0.24 & 0.51 \\
$1<\mathrm{y}<=5$ & 3.09 & 3.34 & 2.14 & 3.27 & 4.11 & 3.95 & 3.40 & 2.55 & 1.97 \\
$5<\mathrm{y}<=10$ & 9.65 & 6.99 & 6.72 & 6.50 & 6.98 & 7.61 & 7.29 & 7.46 & 6.99 \\
$10<\mathrm{y}<=15$ & 13.59 & 11.80 & 11.94 & 11.04 & 11.93 & 14.33 & 12.65 & 14.05 & 13.79 \\
$\mathrm{y}>15$ & 0.00 & 0.00 & 16.01 & - & 19.98 & 17.39 & 16.31 & 23.06 & 22.13 \\
\hline Total Private Sector & 3.70 & 6.53 & 2.81 & 5.04 & 5.89 & 5.81 & 4.71 & 6.94 & 11.51 \\
Total bond portfolio & 5.80 & 7.30 & 6.50 & 11.80 & 13.70 & 15.00 & 13.40 & 13.60 & 14.20 \\
\hline
\end{tabular}

Source: CNSF

Notice that average maturity of the whole bond portfolio has been increasing in the last nine years from less than six years to more than 14 years. The increase is more 
noticeable in the year 2000 when asset liability matching rules were introduced as part of the solvency margin calculation for annuity companies. While maturity of assets has increased, the average maturity of the liabilities, estimated with the expected longevity is of 37 years.

Given the maturity mismatch mentioned above, it is safe to assume also a duration mismatch between assets and liabilities and therefore, provide a preliminary assessment on the duration methodology used for measuring, monitoring and managing interest rate risk by pension annuity companies. Duration (modified, or Macauly) is a good measure of sensitivity to marginal changes in interest rates of option-free bond portfolios. Duration is typically defined as the approximate percentage change in the price for a 100 basis point parallel shift in the yield curve. Pension annuity companies have large positions of government bonds known as UDIBONOS (Bonos De Desarrollo Del Gobierno Federal Denominados En Unidades De Inversión), PICs (Pagarés de Indemnización Carretera con aval del Gobierno Federal) and CBICs (Certificados Bursátiles de Indemnización Carretera con aval del Gobierno Federal) that have maturities between seven and 28 years. These are fixed coupon non-callable bonds and therefore have no embedded options. ${ }^{24}$ In other words, measuring the interest sensitivity of a portfolio of CBICs with duration is correct. ${ }^{25}$ Duration is also a good measure of interest rate sensitivity of the liabilities of pension annuity companies in Mexico as liability cash flows are not interest rate sensitive.

However, while duration is a good measure of interest rate sensitivity it is not a perfect measure. Its major limitation relates to the fact that it is a good approximation of price changes only: (1) when interest rate risk stems from only parallel shifts in the yield curve; and (2) when interest rate risk stems from only small changes in interest rate. Due to these limitations, the CNSF may want to extend the metrics required by pension annuity companies to measure interest rate sensitivity.

A first metric used to address the second limitation mentioned above is convexity. Convexity is a second-order term that measures the change in price from the duration estimate for a small change in rates. For instance, for a positive duration instrument with no embedded options, positive convexity means that the duration extends (increases) when interest rates fall, and the duration shortens (decreases) when interest rates rise. ${ }^{26}$ Duration and convexity would take care of the asymmetric percentage change in prices of bonds when the yield curve shifts upwards or downwards. In other words, the two metrics together can measure interest rate risk for large interest rate changes. Typically, in an asset liability management (ALM) strategy it is required that the convexity of assets

\footnotetext{
${ }^{24}$ A bond with an embedded option is generally a bond the expected cash flow of which changes when interest rates change. Typically this happens in variable coupon bonds, in bonds that can be called by the issuers or in mortgage backed bonds where there is a prepayment risk that is a function of the level of interest rates.

${ }^{25}$ For bonds with embedded options like mortgage backed securities, variable coupon bonds or corporate callable bonds other interest rate sensitiveness measures need to be used.

${ }^{26}$ All fixed cash-flow bonds have positive duration and positive convexity. Securities with embedded options may have regions with negative or reduced positive convexity. For example, home mortgages can have negative convexity as rates lower and increase the likelihood of prepayments, resulting in lower duration as rates fall, and convexity may turn positive from lower likelihood of prepayment or extension resulting in greater duration as rates rise.
} 
be larger than the convexity of liabilities. If this is the case, when interest rates increase, the value of assets decreases by less than the value of liabilities while when interest rates decrease, the value of assets increases by more than the value of liabilities.

A second metric commonly used to address the first limitation mentioned above are key rate or partial duration. Hardly does the yield curve shifts in parallel. More often the curve twists (it becomes flatter or steeper) or changes in curvature (butterfly shifts). Key rate duration, or partial duration, measure the local sensitivity to a shift in just a portion of the yield curve. Key rate duration or partial duration are useful metrics when one wishes to measure a portfolio's sensitivity portfolio to movement in various parts of the yield curve. ${ }^{27}$ By matching partial durations of asset and liability portfolios it is possible to obtain a substantial degree of protection against nonparallel shifts in the yield curve. In addition, key rate shifts are constructed so that their sum equals a parallel shift and thus the sum of key rate durations is equal to effective duration for fixed cash flow instruments. ${ }^{28}$

Finally, the requirement for companies to be fully duration matched aims at immunizing assets and liabilities, this may not be consistent with other company policies such as surplus management policies or yield enhancement policies. For instance, companies may be interested in immunizing the surplus from changes in interest rate and therefore they would match assets and liabilities in terms of dollar duration, rather than simpler duration.

Alternatively companies may want to adopt yield enhancing tactics by having shorter asset duration if they believe interest rates will be increasing. The considerations just made are purely tactical and provide an argument for allowing companies to maximize their competitive advantage. This does not mean that other measures should not be preferred from the supervisory point of view. However, they constitute a valid argument for supervisory authorities for using a diverse set of risk metrics for prudential rules.

\section{II.E Market Performance}

Company performance is determined by jointly underwriting and reserve investment performance. In this section we discuss separately underwriting and investment performance and their impact on solvency of pension annuity companies.

\section{Underwriting performance}

Underwriting performance is usually measured by four basic ratios: the loss ratio (LR), the operational expense ratio (OR), the underwriting expense ratio (UR), and the combined ratio (CR). The LR measures net accrued claims as a proportion of net earned premiums, i.e., gross claims paid less claim provisions at the beginning of the year plus

\footnotetext{
${ }^{27}$ Key rate and partial durations are essentially the same concept. The only difference is that key rate durations are calculated by shocking the spot rate curve while partial durations are calculated by shocking the yield curve.

${ }^{28}$ See Ho (1992), Reitano (1992), Fabozzi and Fong (1994), and Dettatreya and Fabozzi (1995) for various alternative metrics that follow the approach just described.
} 
claim provisions at the end of the year less the receipt from reinsurers over gross premiums received less premiums ceded (net or retained premiums) less premium provisions at the end of the year plus premium provisions at the beginning of the year. It shows the percentage of premiums that are paid back to the insured and a high ratio normally indicates an efficient and competitive industry while a low ratio would indicate relative inefficiency. Notice that since payments for claims are spread in the pension annuity market over a number of years, insurance companies make transfers to loss reserves to cover future payments. Differences in reserving policies for tax and other purposes reduce the usefulness of the loss ratio as an index of efficiency. Hence, an index average over two or more years is often taken. The OR is computed as general administrative expenses (wages and other labor costs, rental and other utilities), plus marketing and other support services like IT and legal services as a proportion of gross premium income. The UR is computed as general underwriting expenses like net commissions paid (i.e., commissions paid to agents less commissions received from reinsurers) as a proportion of gross premiums and in the case of pension annuity providers in Mexico, premiums for the purchase of additional benefits need to be added. Gross premium is used as the basis for calculating the OR and the UR because acquisition costs and general administrative costs are incurred for the generation of gross premiums, and not just retained premiums. The CR is simply the sum of the three ratios just mentioned. Notice that it is common practice worldwide to sum indices with different denominators, despite this being mathematically incorrect, as the LR typically represents more than 90 percent of the CR. In other words, the possible distortion introduced by this practice can be easily ignored.

Figure 3 reports the evolution of the average underwriting performance between 1997 and 2005 for the Mexican pension annuity market. Underwriting performance displays a similar pattern of progressive deterioration we are now familiar with other variables. Average loss ratios in 1997 exceeded 140 percent due to the fact that many companies were trying to establish a reputation in the annuity market and gain market shares by offering very generous additional benefits. After this initial year underwriting performance has always been positive but progressively deteriorating until 2002 when it exceeded 100. The general trend in increasing underwriting and operational costs is due to the decrease in gross premium income since 2002 and the need to invest in a more qualified and professional sales force. In an environment of decreasing investment performance (see later) companies could not afford to compete on the basis of generous additional benefits anymore. In other words, substantial training and expanded sales forces were needed to attract new customers. This is particular evident in 2003 when companies realized that the growth of new business was going to be lower than expected and needed to adapt to the less profitable environment by improving their distribution channels. 
Figure 3: Evolution of Average Underwriting Performance

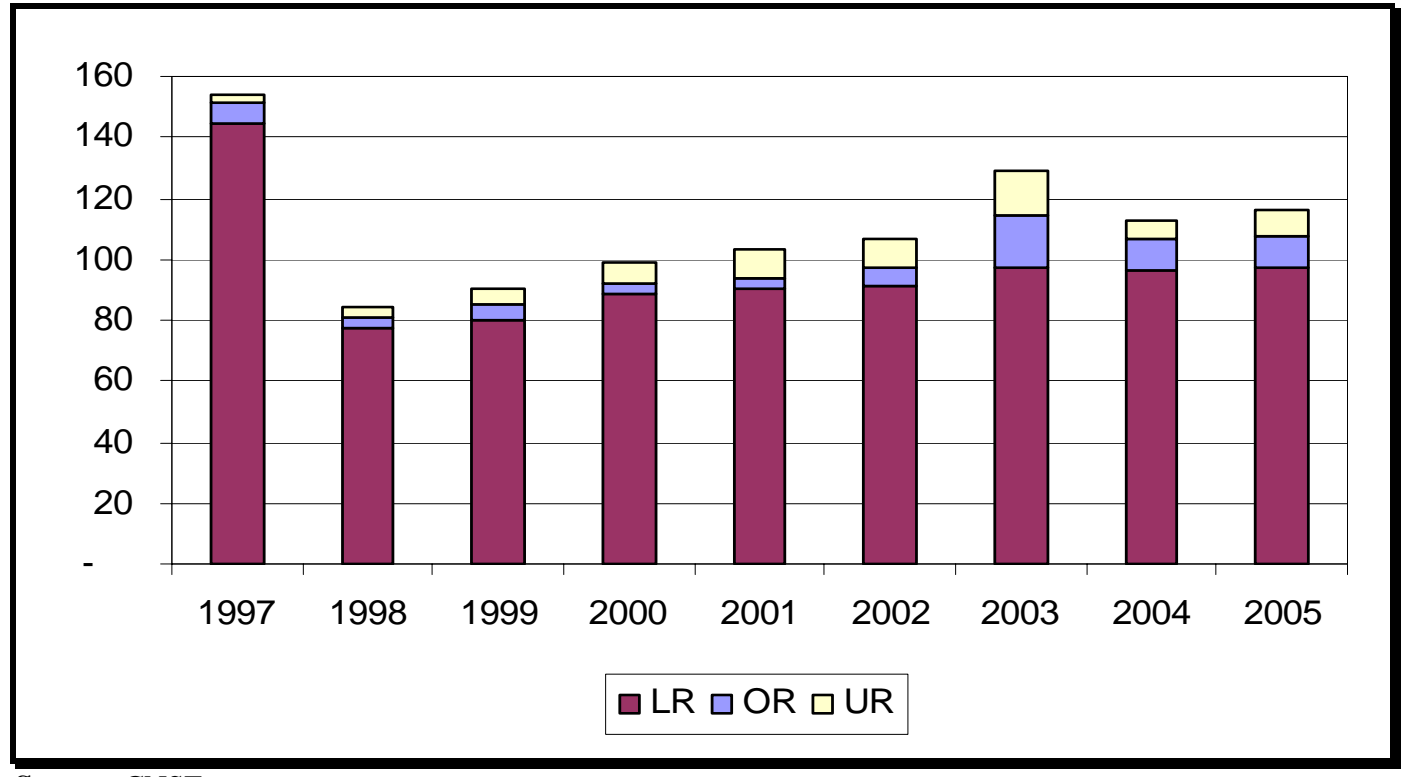

Source: CNSF

It is important to notice how the worsening underwriting performance of pension annuity companies in Mexico is not due to inefficiencies. The real reason for the worsening underwriting performance since 2002 is the drastic fall in gross premium income (the reasons for which are discussed in detail in section III) and the delayed cost structure adjustments that companies have introduced. The next table reports the evolution of gross premium income and underwriting costs divided in pure underwriting costs and costs related to premiums for additional benefits. It essentially reports the UR data showed in the previous figure.

Table 15: Evolution of Average Underwriting Costs, MXN Million, 2001-2005

\begin{tabular}{lrrrrrrrrrr}
\hline & $\mathbf{2 0 0 1}$ & $\mathbf{\%}$ & $\mathbf{2 0 0 2}$ & $\mathbf{\%}$ & $\mathbf{2 0 0 3}$ & $\mathbf{\%}$ & $\mathbf{2 0 0 4}$ & $\mathbf{\%}$ & $\mathbf{2 0 0 5}$ & $\mathbf{\%}$ \\
\hline GPI & $16,640.59$ & & $10,261.26$ & & $3,501.71$ & & $5,224.7$ & & $4,504.33$ & \\
Pure Underwriting & 403.90 & 2.4 & 288.70 & 2.8 & 173.96 & 5.0 & 162.5 & 3.1 & 203.26 & 4.5 \\
Additional Benefits & $1,178.58$ & 7.1 & 695.98 & 6.8 & 332.21 & 9.5 & 156.14 & 3.0 & 177.67 & 3.9 \\
\hline Total Underwriting & $1,152.48$ & 9.5 & 984.68 & 9.6 & 506.18 & 14.5 & 318.64 & 6.1 & 380.93 & 8.5 \\
\hline
\end{tabular}

Notes: 1/ Real 2005 pesos

Source: CNSF

The sudden increase in the underwriting expense ratio (the same could be said as far as operational expenses, not reported in the table, are concerned) in 2003 was due to the sudden drop in premiums from 2002 onwards that was only partially offset by the decrease in underwriting costs over the same period. Gross premium income in 2003 was 34 percent of gross premium income of 2002. Pure underwriting costs (agent fees) in 2003 were only 60 percent of the value of 2002 while premiums for additional benefits decreased in 2003 to 48 percent the values of 2002. In other words, companies were 
rather quick to adjust the generosity of additional benefits but not as quick in adjusting the commission levels paid to agents. Such adjustments took place only between 2004 and 2005 that brought the overall underwriting expense ratio to 8.5 percent, a level lower than in 2001.

\section{Investment performance}

The problem of combined ratios is that they are frequently negative (or equivalently, above 100 percent as shown in Figure 3). In other words, they are not very informative of the profitability of a company if not analyzed in conjunction with the investment performance. As a way of example, the following table reports a summary analysis of profitability of non-life markets in select industrialized countries. Notice how the combined ratio is almost constantly above 100 percent, meaning that markets are profitable only with good investment performance.

Table 16: Evolution of Average Non-Life Loss Ratios in Select Countries (in Percent)

\begin{tabular}{|c|c|c|c|c|c|c|}
\hline & USA & CAN & GBR & DEU & FRA & JPN \\
\hline & '94- '04 & '94 - '04 & '94-'04 & '94-'04 & '95- ‘04 & '96 - '04 \\
\hline Loss ratio & 78.7 & 73.3 & 73.0 & 71.3 & 80.8 & 61.2 \\
\hline Expense ratio /1 & 26.4 & 29.8 & 31.2 & 27.5 & 23.3 & 38.1 \\
\hline Policy holder dividend ratio & 1.1 & n.a. & n.a. & n.a. & 1.1 & 0.1 \\
\hline Combined ratio & 106.2 & 103.1 & 104.2 & 99.9 & 105.2 & 99.4 \\
\hline Investment performance & 16.2 & 13.8 & 16.8 & 15.4 & 13.4 & 4.7 \\
\hline Profit margin (pre tax) & 9.2 & 10.4 & 12.8 & 12.7 & 7.0 & 4.4 \\
\hline
\end{tabular}

Notes: 1 / this is comparable to underwriting expense and operational expense ratios for the Mexican pension annuity industry.

Source: Holzeu Lechner (2006).

Hence, the final element of a company performance is given by the rate of return that can be generated from reserves. As previously mentioned, pension annuity companies invest reserves in government debt. With increased fiscal discipline, sovereign risk and inflation pressure decreased considerably. The next figure reports the evolution of inflation and sovereign risk for Mexico. This is measured by the JP Morgan EMBI+; i.e., the interest rate difference between Mexico and US Treasury Bills. As of November 22 2005, this was at historical lows of 112 basis points. 
Figure 4: Evolution of Sovereign Risk and Inflation

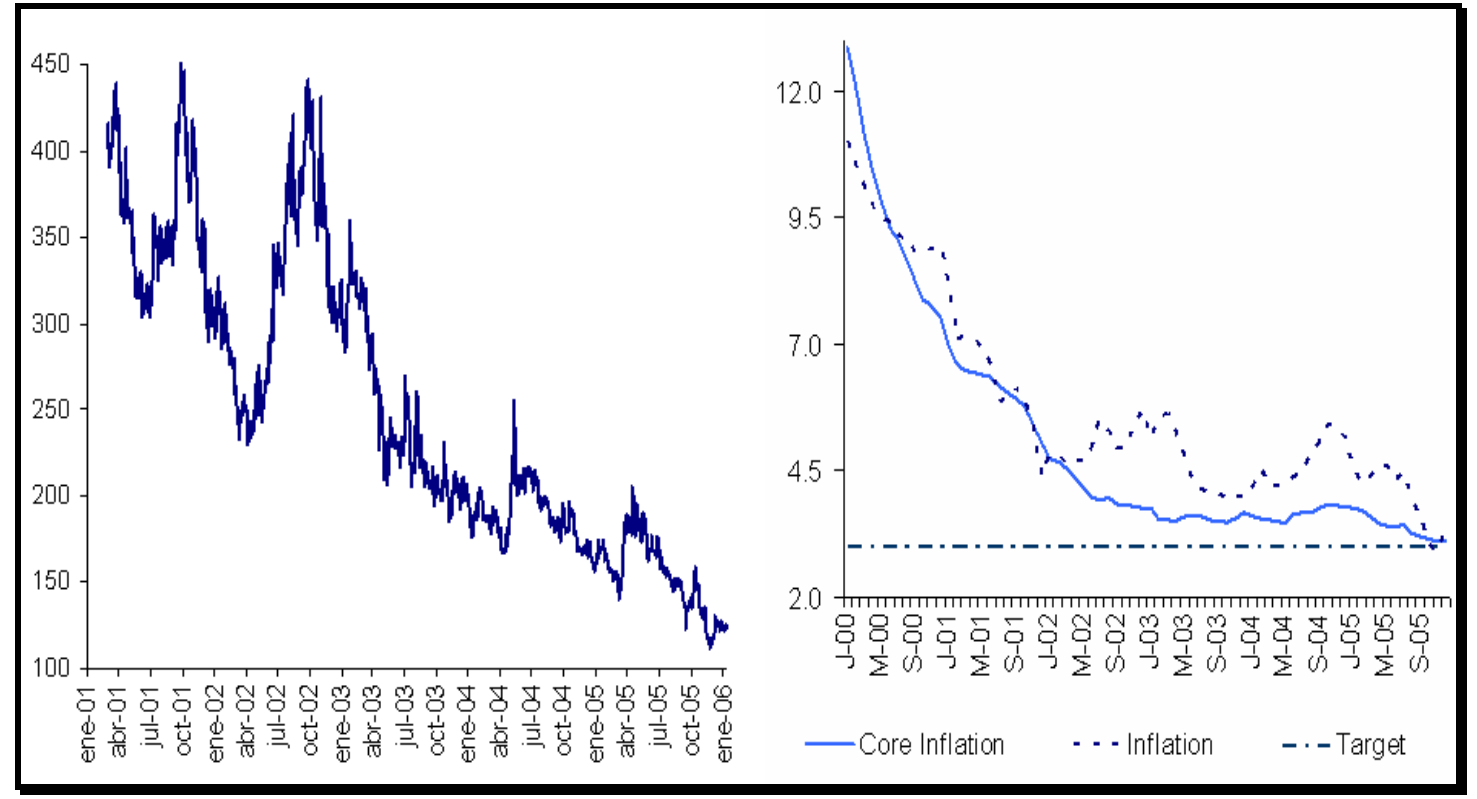

Source: CNSF

The improved macroeconomic environment enabled the central bank to decrease interest rates and the next figure reports the evolution of companies' financial results and reference interest rates such as the rate of $\operatorname{Cetes}^{29}$ and $\mathrm{CPP}^{30}$. Given the exposure to interest rate sensitive instruments, the investment performance of annuity companies has deteriorates as shown in the next figure. After reaching a record investment return performance of 20 percent nominal in 1998, average nominal rates over the 2002 and 2005 period have decreased to 6.1 percent.

Pension annuity companies have large positions of government bonds known as UDIBONOS (Bonos De Desarrollo Del Gobierno Federal Denominados En Unidades De Inversión), PICs (Pagarés de Indemnización Carretera con aval del Gobierno Federal) and CBICs (Certificados Bursátiles de Indemnización Carretera con aval del Gobierno Federal). The long term real interest rate, in the case of $10 \mathrm{yr}$ Udibonos have passed from 7.14 percent in October 1999 to 4.30 in December 2005 and to 5.09 percent in June 2006; in the case of PICs the long term real interest rates have passed from around 6.13 percent in October 2001 to around 5.94 percent in November 2002 and in the case of 20 and 30 yr CBICs the long term real interest rates decreased from 6.16 and 6.21 percent in January 2003 to 4.59 and 4.68 percent in December 2005, in that order.

\footnotetext{
${ }^{29}$ CETES (Treasury Certificates) Zero coupon bills denominated in pesos issued by the Mexican government. CETES are the Mexican counterparts of U.S. Treasury bills.

${ }^{30}$ CPP (Commercial Bank's Average Cost of Term Deposits) covers term deposits, certificate of deposits, other current account deposits (other than demand deposits), banker's acceptances and commercial paper with bank guarantee.
} 
Figure 5: Evolution of Investment Performance and Key Interest Rates

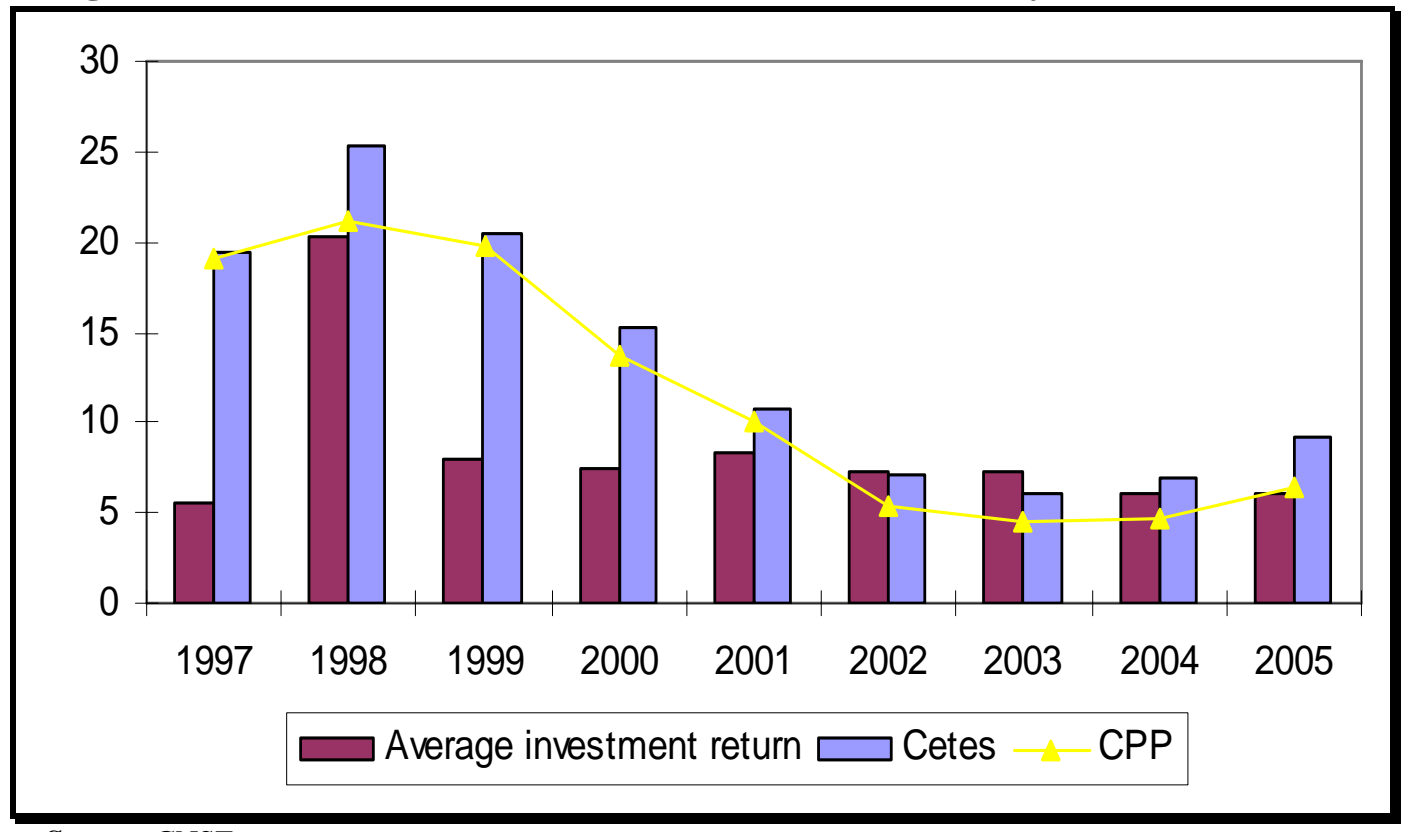

Source: CNSF

Clearly, especially for new business, the decrease in yield on fixed income paper is lowering the profit margins of the pension annuity sector. However, this has so far not translated in lowered solvency margins as discussed in the next section.

\section{Solvency}

Beside the technical provisions that companies must constitute in order to meet obligations arising form contracts with policyholders, solvency rules contained in the LGISMS require companies to establish a Minimum Guarantee Capital (Capital Mínimo de Garantía, CMG). The CMG is used to face possible deviations as a result of variations from expected claims, the breakdown in payments due to insolvent reinsurers, and adverse fluctuations in asset valuation as well as mismatches between assets and liabilities. In this respect the CMG requirements seek to strengthen the financial solvency and viability of institutions as a function of their volume of operations as well as the type or risks underwritten.

CNSF (2006b) contains a detailed description of the solvency rules applying to all insurance companies in Mexico. It is interesting to notice that, the methodology for the estimation of the CMG also incorporates a requirement to cover possible losses resulting from the exposure to credit, inflation and interest rate risk in the investment of technical provisions. In order to do this, the CNSF establishes a system of asset liability matching that includes weights to measure the impact that eventual mismatches would have on capital. The weighing system is a function of the availability of investment instruments of different maturities in the market and it depends among other things on the volume and 
frequency of issues in the primary market, availability and liquidity on the secondary market.

Table 17: Weighting System for Asset Liability Mismatches

\begin{tabular}{cc}
\hline Year of Projection & $\mathbf{W}_{\mathbf{k}}$ \\
$\mathrm{k}<=5$ & 1 \\
$5<\mathrm{k}<=6$ & 0.96 \\
$6<\mathrm{k}<=7$ & 0.94 \\
$7<\mathrm{k}<=8$ & 0.85 \\
$8<\mathrm{k}<=9$ & 0.78 \\
$9<\mathrm{k}<=12$ & 0.51 \\
$12<\mathrm{k}<=14$ & 0.46 \\
$14<\mathrm{k}<=15$ & 0.42 \\
$15<\mathrm{k}<=17$ & 0.37 \\
$17<\mathrm{k}<=18$ & 0.30 \\
$18<\mathrm{k}<=19$ & 0.25 \\
$19<\mathrm{k}<=20$ & 0.24 \\
$20<\mathrm{k}<=21$ & 0.23 \\
$21<\mathrm{k}<=23$ & 0.20 \\
$23<\mathrm{k}<=24$ & 0.19 \\
$24<\mathrm{k}<=25$ & 0.17 \\
$25<\mathrm{k}<=27$ & 0.13 \\
$27<\mathrm{k}<=28$ & 0.08 \\
$28<\mathrm{k}<=29$ & 0.02 \\
$29<\mathrm{k}<=30$ & 0.01 \\
$\mathrm{k}>30$ & 0.00 \\
&
\end{tabular}

Source: CNSF

Table 17 reports the weighting system provided by the CNSF to the industry to weigh eventual mismatches between assets and liabilities in the calculations of the CMG as of March 2006. The weighting system is regularly updated by the CNSF and communicated to the industry when the situation in the financial market requires it. Notice that the weighting system decreases with time reflecting the lack progressive unavailability of longer term instruments.

Ideally, all weight should be equal to one and if this were the case, the CNSF estimates that companies would need to set aside an extra amount of capital equivalent to 25 percent of current technical provisions (or MXN 18,410 million). The methodology used to calculate additional capital requirements in the presence of asset liability mismatches appears to follow a "regulatory maturity gap approach" to asset liability management. It is not clear how this complements or substitutes the economic duration approach that companies need to follow when measuring and monitoring risks. For instance, no reference was found in regulations on the impact that such economic ALM framework based on duration metrics has on capital. Besides, a maturity gap analysis 
that by regulation puts zero, or tending to zero, weights on maturity mismatch on long term maturities may underestimate the interest rate risk stemming from yield curve movements in the same region; i.e., there may be a need to complement this with an economic maturity gap analysis that uses unit weights at all maturities. In any case, maturity gap analysis (weighted, like in Mexico, or not weighted, as generally used) is a marked improvement on any ALM framework observed in all jurisdictions in the region, and clearly a vast improvement on ad hoc fixed paid up capital rules. However, it is no substitute of a full fledged ALM framework for ongoing monitoring and controlling the various types of risks that stem from the asset and liability side of the balance sheet.

As a result of the underwriting and investment performance of pension annuity companies over the last nine years, as well as the specific structure of assets and liabilities that obviously affect the solvency margin, the regulatory solvency position of pension annuity providers (measured in terms of MXN in excess of the required CMG) and other performance indicators like ROE and ROA have improved over time as reported in the next table.

Table 18: Pension Annuities Solvency and Profitability Indicators (1997-2005)

\begin{tabular}{lrrrrrrrrr}
\hline & $\mathbf{1 9 9 7}$ & $\mathbf{1 9 9 8}$ & $\mathbf{1 9 9 9}$ & $\mathbf{2 0 0 0}$ & $\mathbf{2 0 0 1}$ & $\mathbf{2 0 0 2}$ & $\mathbf{2 0 0 3}$ & \multicolumn{1}{c}{$\mathbf{2 0 0 4}$} & \multicolumn{1}{c}{$\mathbf{2 0 0 5}$} \\
\hline Solvency Margin (MXN million) & 667.2 & 292.5 & 811.3 & 862.0 & 570.8 & 829.1 & $2,176.8$ & $1,761.2$ & $2,927.5$ \\
ROE (percent) & -8 & -29.2 & -20.2 & -19.8 & -6.4 & 15.6 & 22.5 & 26.1 & 24.3 \\
ROA (percent) & -2.9 & -3 & -1.2 & -0.9 & -0.3 & 0.7 & 2.9 & 4.0 & 1.9 \\
\hline
\end{tabular}

Source: CNSF

There is a seeming contradiction between, on the one hand, the sudden decrease in premiums since 2002, the worsening of the underwriting profitability and the decrease in investment yield and, on the other hand, the improvement over time in the solvency margin. One possible explanation for this is that the size of assets corresponding to the more important portfolio of business (in relative terms) is still growing quickly enough to compensate for the other negative trends mentioned before related especially to the reduced new business. Another possible explanation is that companies are still obtaining high levels of ROE and ROA for assets invested at higher yields in the past.

Alternatively, it is possible that the worsening of the underwriting performance, together with lower long term yield on fixed income paper has indeed translated in lower economic solvency margins for the industry in the medium term. However, this is not disclosed by the regulatory solvency margin due to its low weights on long term mismatches between assets and liabilities. The adoption of other forms of solvency margins based on economic capital, at least for prudential purposes, would enable the CNSF to better monitor the economic solvency of the industry and take eventual appropriate remedial actions. ${ }^{31}$

\footnotetext{
${ }^{31}$ Notice, that the CNSF has completed and implemented a dynamic solvency model, an important step toward the adoption of statutory solvency rules envisioned within the Solvency II framework. The model uses historical data to construct claim distributions for different lines of business. It allows the CNSF to calculate the probability of capital shortages of each insurance company by stressing variables that affect its
} 


\section{Development Prospects For The Pension Annuity MARKET}

In the previous section two distinct periods were identified in the evolution of key variables and performance of the pension annuity market in Mexico. Between 1997 and 2002 the annuity market witnessed rapid growth while starting with 2002, the volume of gross premium income drastically dropped. In this section we shed light on the reasons for such change in market growth.

Disability pension benefits provided for under the LSS-73 were based on the nominal average base salary of the last 500 weeks of contributions. Art 167 of the LSS-73 defined the methodology for calculating such benefits linking them to the individual's years of contributions according to a table published in the same article. Benefits were originally indexed to the minimum salary in the Federal District. In addition to the disability pension, insured members were eligible for pension increments on the basis of family allowances and other forms of social assistance.

With the 1997 reform, the new IV benefit is defined as 35 percent of the average individual base salary during the last 500 weeks of contribution and indexed to the INPC. Minimum IV pension under the new rules is defined as the minimum salary in the Federal District as of July $1^{\text {st }}, 1997$ which is itself indexed to the INPC. Similarly to the provisions of LSS-73, insured members are eligible for IV pension increments on the basis of family allowances and other social assistance. The IV benefits provided for under LSS-97 were designed to be on average more generous than the disability benefit provided for under LSS-73. Also, with the reform, IV immediate premium annuities were going to be purchased by the IMSS, with the accumulated reserve stemming from a 2.5 percent contribution rate, from private sector specialized pension annuity providers.

The structure of the new pension system allowed to promote the development of a private sector annuity market before new entrants into the labor force started retiring and demanding old age pensions. ${ }^{32}$

Such rationale was also followed by Chile that experienced a rapid growth of the annuity market and currently has a very competitive annuity market providing very good annuity values to retirees (see section II.B). Countries that have introduced a second, private

underwriting and overall profit. The output of this exercise guides conversations with the industry to monitor the solvency situation and the adequacy capital requirements and technical reserves. Two issues related to this dynamic model are worth mentioning here. The model is not yet a true dynamic ALM where assets and liabilities are modeled jointly. At present asset risk is modeled only through the use of VaR techniques and separately from liabilities. Also, the model does not exploit possible correlation among the liability distributions of different lines of business and each claim distribution is treated as independent from the others. As far as the first issue is concerned, the CNSF is working towards a more general model that integrates assets and liabilities. As far as the second issue is concerned, the CNSF argues that little correlation exists in practice among claim distributions of different lines of business. While such property of the model would be desirable, it would provide only marginal value added. (See CNSF 2006e)

${ }^{32}$ It is worth re-calling at this point that the so called "transitional cohort," i.e., individuals with at least one contribution at the time of the 1997 reform, is allowed to opt for the old age pension provided for under LSS-73. 
pillar as part of their pension reform, and that have shifted disability and survivorship insurance to the new pillar, either partly or totally, may also experience this rapid growth effect. Some reforming countries in Central and Eastern Europe have decided to maintain disability insurance in the first, public pillar, because of concerns about the capacity of the insurance industry to deliver this benefit efficiently, and because of the perception that disability and other programs such as health and sick pay can only be well integrated in the public sector. These concerns may be legitimate and may justify keeping disability in the first pillar in several countries. However, this policy will also imply a slower growth of the annuities market.

Since 1997, several reforms were implemented that altered the philosophy underpinning the provision of IV benefits after the 1997 reform. In 2001, the indexation base of pension benefits provided for under LSS-73 was changed from the minimum salary in the Federal District to the INPC. Since, average wage growth after the 1997 reform has been lower than inflation this reform increased the generosity of the 1973 benefits relatively to the 1997 benefits. $^{33}$ In 2002, a second reform of the LSS-97 was passed allowing individuals who retired under the provision of LSS-73 to withdraw as a lump sum the balance of the 2 percent accumulate contributions for old age pension in the RCV subaccount. ${ }^{34}$ The permission to withdraw the accumulated balance from the old age contribution in the RCV accounts increased the generosity of the pension provisions under LSS-73 relatively to the now reformed provisions under LSS-97. In addition, the IMSS was given the authority to interpret the provisions under the LSS-97 and it extended the option of electing benefits under LSS-73 also to IV benefits.

After the 2002 reform, known as the SAR-02 reform, insured members could then choose between two types of disability benefits as summarized in the following table.

\footnotetext{
${ }^{33}$ Wage inflation is traditionally higher than price inflation over long period of times. Clearly, the statement is valid only with respect to the specific period of time mentioned.

${ }^{34}$ This refers to the accumulated balance of the 2 percent contribution after 1997 in the RCV sub-account (see first line, third column in Table 1). Notice that the SAR-97 reform had already allowed individuals opting for benefits provided for under LSS-73 to withdraw as a lump sum the accumulated balance between 1992 and 1997 in the SAR-92 account (see first line, second column in Table 1).
} 
Table 19: Disability Benefits Under LSS-73 and LSS-97

\begin{tabular}{|c|c|c|}
\hline & LSS-73 & LSS-97 \\
\hline Salary base & $\begin{array}{l}\text { Average of last } 500 \text { weeks of } \\
\text { contributions not indexed }\end{array}$ & $\begin{array}{l}\text { Average of last } 500 \text { weeks of } \\
\text { contributions indexed to the } \\
\text { INPC }\end{array}$ \\
\hline Basic pension & $\begin{array}{l}\text { Following table in Art } 167 \text { of } \\
\text { LSS-73. }\end{array}$ & 35 percent of salary base \\
\hline Minimum pension & $\begin{array}{l}\text { Minimum salary of the Federal } \\
\text { District at the time of pension. } \\
\text { (MXN 1,402 as of July 2004) }\end{array}$ & $\begin{array}{l}\text { Minimum salary of the Federal } \\
\text { District as of July } 1997 \text { indexed } \\
\text { to INPC (MXN 1,551 as of } \\
\text { July 2004). }\end{array}$ \\
\hline Pension indexation & INPC (As per reform of 2001) & INPC \\
\hline SAR-92 (92-97) account & $\begin{array}{l}\text { Balance payable in the form of } \\
\text { lump sum }\end{array}$ & $\begin{array}{l}\text { SAR 92-97 balance payable in } \\
\text { the form of lump sum }\end{array}$ \\
\hline $\begin{array}{l}\text { Old age cash balance in RCV } \\
\text { subaccount }\end{array}$ & $\begin{array}{l}\text { Balance payable in the form of } \\
\text { lump sum (As per reform of } \\
\text { 2002) }\end{array}$ & Not applicable \\
\hline
\end{tabular}

Source: Fernandez Reyes (2004)

The increased relative generosity of the 1973 provisions and the fact that the IMSS granted the option of electing IV benefits under such provisions and opted for tightened eligibility and disability rules, changed the growth prospects of the market and premium growth decreased in the years since 2002 relative to previous years as shown in the next figure.

The only thing left to be explained now is why insured individuals would stop electing disability benefits under the LSS-97 provisions when, on average, these were designed to be more generous than the disability benefits provided under LSS-73, as mentioned before. The following table compares the disability pension that an insured individual would obtain under the provisions of LSS-73 and LSS-97. In order to compare the heterogeneous benefits under the two laws, the old age balance payable in the form of a lump sum from the RCV subaccount when individual elect the LSS-73 was transformed in IV annuity and added to the basic pension the individual would be entitled. 
Figure 6: Impact of SAR-02 Reform on IV Premium Growth

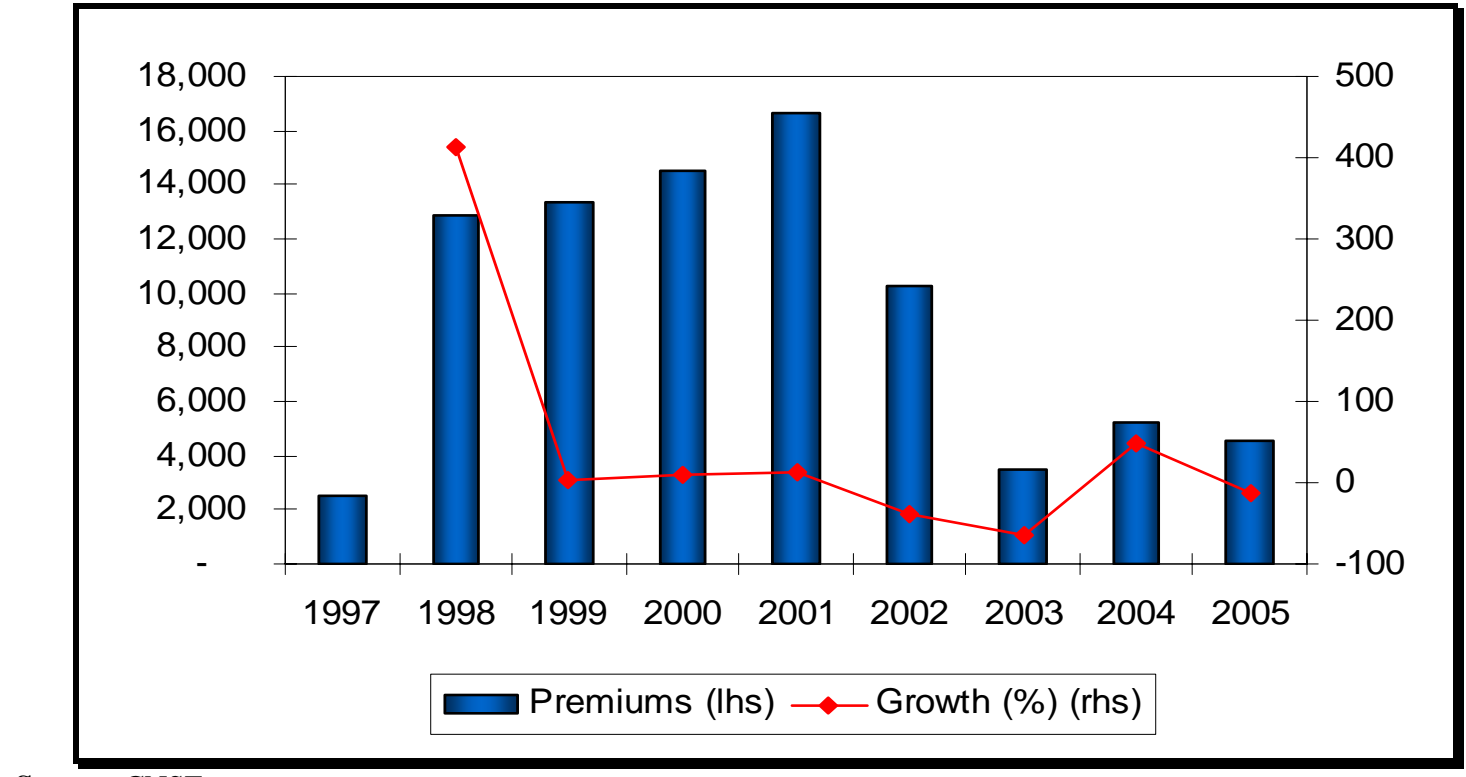

Source: CNSF

Table 20: Monthly Disability Benefit Comparison Under 1973 and 1997 Laws (MXN)

\begin{tabular}{c|ccccc|c}
\hline & \multicolumn{5}{|c|}{ 1973 Law } & 1997 Law \\
\hline Average salary & 5 & 10 & 15 & 20 & 25 & \\
\hline 1,500 & 1,409 & 1,418 & 1,431 & 1,449 & 1,476 & 1,551 \\
3,000 & 1,415 & 1,433 & 1,459 & 1,750 & 2,066 & 1,551 \\
4,500 & 1,422 & 1,449 & 1,709 & 2,236 & 2,786 & 1,575 \\
6,000 & 1,428 & 1,464 & 1,902 & 2,666 & 3,462 & 2,100 \\
7,500 & 1,434 & 1,480 & 2,157 & 3,149 & 4,180 & 2,625 \\
9,000 & 1,441 & 1,495 & 2,443 & 3,656 & 4,917 & 3,150 \\
10,500 & 1,447 & 1,511 & 2,850 & 4,266 & 5,736 & 3,675 \\
12,000 & 1,611 & 1,684 & 3,257 & 4,875 & 6,556 & 4,200 \\
13,500 & 1,802 & 1,894 & 3,665 & 5,485 & 7,375 & 4,725 \\
\hline
\end{tabular}

Source: Fernandez Reyes (2004)

The comparison exercise reported in the previous table suggests that on average, the large majority of individuals (the shaded area) would prefer the benefits under the LSS-97. Only individuals with more than 15 years of contributions and more than twice the minimum salary (the average salary in Mexico is between four and five times the minimum salary) would prefer benefits under the LSS-73 the relative generosity of which was increased by the 2001 and 2002 reforms.

Several reasons can be attributed to the seeming irrational behavior of insured individuals that caused the annualized average decrease of 28 percent in premium since 2001 displayed in Figure 6. 
The IMSS may not be informing the insured individuals about the available options of IV benefits. A casual interpretation of Article IV of the transition provisions of LSS-97 (and IMSS' position) would indicate that the IMSS is not required to compare benefits under the two laws unless insured people require the institute to do so. Unfortunately, the LSS97 is badly written in several articles and this case is not an exception. Clearly, only jurisprudence can establish the correct interpretation of the specific article before mentioned.

In addition, the IMSS is recently making increased use of temporary disability pensions. Eligibility rules for disability benefits were tightened in 2004 and the IMSS is supporting a policy of rehabilitation before declaring individuals disabled. Temporary disability pensions are provided by the IMSS for two years and renewable indefinitely. This has had two major consequences: (1) the number of potential annuitants in the private sector is further reduced; and (2) the pool of annuitants that is covered by pension annuity providers is deteriorating.

The decrease in the long term interest rate and the lower number of new annuitants are lowering the profit margins of the annuity companies as typically, during the early years of marketing of a new product, companies tend to underprice and seek market share. ${ }^{35}$ The lower profitability of the initial products is recuperated through the yield on income paper and the business growth. We have produced in this paper evidence of average deterioration of underwriting performance. Hence, IMSS' behavior has reduced the opportunity of higher profits for insurance companies by reducing the scope for business growth.

The deterioration of the pool of annuitants also impacts profitability. Insurance companies make money by pooling different types together and charging a price that on average is neither too high nor too low: i.e., a price that on average generates reasonable profits. Within the pool, stochastic variations across types are averaged out and the money lost by insuring an individual who ex post lives (say) longer than what ex ante expected is recuperated by insuring an individual who ex post lives less than what ex ante expected. To the extent that the ex post variation in outcomes is only due to stochastic elements, the pool is said to be stable and insurance companies can profitably insure individuals. IMSS' behavior has introduced a systemic element in the pool of annuitants. The use of temporary pensions delays entry of disabled individual in the pool. Since seriously disabled individuals tend to die early, the delayed entry in the pool implies that, on average, individuals insured by private sector companies tend to live longer than expected. In other words, even if we assume that the initial technical parameters that the regulations require companies to use were correct, they are likely to result in a non profitable, or less profitable product once delayed entry is taken into consideration.

But why would the IMSS encourage individuals to elect benefits under the LSS-73 law even if this is against their interest? In order to explain this, it is necessary to analyze the possible states of the world for an individual in the transition cohort (i.e., who has the option to elect IV benefits under the two laws) who is declared disabled by the IMSS and

\footnotetext{
${ }^{35}$ In the Mexican case "underpricing” appears to have taken place through the offer of generous additional products. This is due to the fact that IV and RT benefits are defined by the LSS-97.
} 
determine the payoffs for the federal government, the IMSS and the insured individual in all these states. This is done with the aid of the next table.

The simplest case is when the individual elects benefits under LSS-73. This is described in the last column of the next table (Case E). Independently of whether the base pension (PB) calculated with the use of Art 167 of LSS-73 is higher than the minimum pension guarantee (PMG) the individual withdraws the cash balance in the SAR-92 account and the old age cash balance in the RCV subaccount. The rest of the cash balances in the housing and RCV subaccounts are collected by the federal government that will grant the annuity or the minimum pension (if the base pension is lower than the minimum pension guarantee). In both cases, the IMSS is not required to transfer to the federal government the portion of the reserve accumulated by the 2.5 percent contribution of the insured individual declared disabled.

Table 21: Choice of IV Benefits Under LSS-73 and LSS-97 For The Transitional Cohort

\begin{tabular}{|c|c|c|c|}
\hline & \multicolumn{2}{|c|}{ LSS-97 } & \multirow{2}{*}{ LSS-73 } \\
\hline & $\mathbf{C B}>\mathbf{M C}$ & $\mathbf{C B}<\mathbf{M C}$ & \\
\hline $\begin{array}{l}\sum_{\hat{\Lambda}}^{0} \\
\hat{0} \\
\hat{a}\end{array}$ & $\begin{array}{l}\text { Case A. } \\
\text { - IMSS buys PB } \\
\text { - Insured collects SAR-92. } \\
\text { - IMSS collects CB in housing } \\
\text { and RCV subaccounts } \\
\text { - IMSS retains the difference } \\
\text { with the MC. }\end{array}$ & $\begin{array}{l}\text { Case B. } \\
\text { - IMSS buys PB } \\
\text { - Insured collects SAR-92. } \\
\text { - IMSS collects CB in housing } \\
\text { and RCV sub-accounts. } \\
\text { - IMSS complements the } \\
\text { difference with the MC. }\end{array}$ & \multirow{2}{*}{$\begin{array}{l}\text { Case E. } \\
\text { - Fed Gov pays BP or PMG. } \\
\text { - IMSS' reserve is untouched } \\
\text { - Insured collects cash balance } \\
\text { in SAR-92 and old age in RCV } \\
\text { subaccount }\end{array}$} \\
\hline $\begin{array}{l}0 \\
\sum_{0}^{0} \\
\bar{v} \\
0 \\
0\end{array}$ & $\begin{array}{l}\text { Case } \mathbf{C} \text {. } \\
\text { - IMSS buys PMG } \\
\text { - Insured collects SAR-92. } \\
\text { - IMSS collects CB of housing } \\
\text { and RCV subaccounts } \\
\text { - IMSS retains the difference } \\
\text { with the MC }\end{array}$ & $\begin{array}{l}\text { Case D. } \\
\text { - IMSS buys PMG } \\
\text { - Insured collects SAR-92. } \\
\text { - IMSS collects CB in housing } \\
\text { and RCV subaccounts } \\
\text { - Fed Gov. complements the } \\
\text { difference with the MC }\end{array}$ & \\
\hline
\end{tabular}

Notes: $\mathrm{CB}=$ Cash Balance, $\mathrm{PB}=$ IV basic pension, $\mathrm{PMG}=$ Minimum Pension Guarantee, $\mathrm{MC}=$ Immediate annuity premium.

If the insured individual elects benefits under the LSS-97, then things are a little more complicated. Four cases need distinguishing. If the basic pension calculated as 35 percent of the average base salary in the last five years is higher than the minimum pension guarantee the individual withdraws the cash balance in the SAR-92 account, the other cash balances (CB) in the RCV and housing subaccounts are collected by the IMSS that purchases the annuity in the private sector by paying an immediate premium. If the immediate premium is lower than the available cash balance, the IMSS retains the difference in the IV reserve (Case A). If the immediate premium is higher than the available cash balances (Case B) the IMSS complements the cash balances with the IV reserve accumulated through the 2.5 percent IV contributions of the working IMSS membership. 
If the basic pension calculated as 35 percent of the average base salary in the last five working years of the insured individual is higher than the minimum pension guarantee the individual withdraws the cash balance in the SAR-92 account, the other cash balances (CB) in the RCV and housing subaccounts are collected by the IMSS that purchases the minimum pension guarantee in the private sector by paying an immediate premium. If the immediate premium for the PMG is lower than the cash balance, the IMSS retains the difference in the IV reserve (Case C). However, if the immediate premium for the PMG is higher than the available cash balances (Case D) the federal government is required to complement the cash balances to enable IMSS to buy the PMG.

The asymmetric impact of the provisions under LSS-73 and LSS-97 on the IV reserve in IMSS is obvious. If individuals elect benefits under LSS-73, the IMSS can charge the federal government and the IV reserve remains untouched. If individuals elect benefits under the LSS-97, the IMSS has to use the IV reserve to complement the cash balances from the housing and RCV subaccounts. Apparently, the federal government has stopped complementing the cash balances for the purchase of the minimum pension guarantee (Case D above).

\section{ConClusions AND Policy CONSIDERATIONS}

The pension annuity market in Mexico is small. As of end of 2005, market penetration was only 0.05 percent of GDP while density was around MXN 43 per capita. Two reasons account for the small size of the market: (1) the overall insurance market is small with penetration of around 1.7 percent of GDP at the end of 2005; and (2) the specific design of the 1997 reform, that created the pension annuity market, was such that only disability and worker's compensation annuities are currently offered by the private sector.

Despite its small size the pension annuity market in Mexico, as well as its regulatory framework, display interesting characteristics that provide lessons for other countries that still need to design the decumulation phase of their newly established second pillars, as well as raising some technical and policy concerns that could hamper in the future the healthy development of the market. These issues are: (1) industrial organization; (2) pricing and competition; (3) the 2002 SAR reform; and (4) the ALM framework for insurance companies and its relationship with solvency. These are discussed in the remainder of this concluding section.

A first issue relates to the industrial organization of the market. In Mexico, only specialized pension annuity companies are allowed to operate in the market. The rationale for this policy choice is related to the mandatory nature of the second pillar and the implicit liability of the government associated with it.

However, from the point of view of reducing the financial risk associated with longevity guarantees it would be preferable that general life insurance companies be allowed to offer pension annuities. General life insurance companies could hedge the unexpected systemic longevity improvements in the annuity portfolio with the resulting unexpected systemic mortality improvement in the pure death portfolio. Natural hedging utilizes the interaction of life insurance and annuities to a change in mortality to stabilize aggregate 
cash outflows. Empirical evidence (Cox and Lin 2005) suggests that natural hedging is an important factor contributing to annuity price differences. These differences become more significant for those insurers selling relatively more annuity business. However, most insurance companies would still have considerable net exposure to mortality risks even if they reduced their exposure by pooling individual mortality risk and by balancing their annuity positions against their life positions (Dowd et al. 2004 and Blake et al. 2006). This would imply that longevity risk needs diversifying with the use of longevity linked instruments possibly issued by the government or international organizations.

A second issue relates to pricing and competition. Prudential mortality and technical parameters for pricing are fixed by regulation so that any given annuity provider can only offer one price to any given pensioner. In order to promote competition for annuity products, pension annuity providers are allowed to offer additional benefits such as additional annuity benefits or life insurance products by purchasing them from other insurance companies. The rationale for this policy decision is again related to the legal constrains the mandatory nature of the pension second pillar and the objective of not exposing prospective annuitants to unfair pricing by pension providers.

The competition on additional benefits makes it difficult to compare offers from different companies. It would be preferable that from the point of view of transparency, providers competed only on the basis of the pension benefit. While this would increase transparency it would create additional issues that need to be addressed. The experience in Chile, where prices are not regulated, suggests that the annuitants can obtain very high money's worth ratios on their annuities despite some price variation across ages and premium levels. Price deregulation should be accompanied by strong measure to maintain transparency in the quotation system for annuities and to curb eventual inappropriate market conduct by brokers. Again, the Chilean experience reported in the text can serve as guidance.

Another argument against price regulation of annuities relates to solvency of pension annuity providers and the quality of services they can afford to customers; i.e., to customer protection. For instance, the mortality tables used are experimental tables based on population averages and annuity companies would need to develop their own annuitant mortality tables when sufficient mortality experience is accumulated. This is especially urgent since pension policy changes introduced in 2002 have altered the demographic assumptions at the basis of the pricing framework adopted in 1998 so that the IV annuitant pool is quickly degenerating (see next paragraph). Also, the long term real interest rate has moved from around 7.14 percent in October 1999 to 4.30 percent in December 2005 and 5.09 percent in June 2006 in the case of 10 yr Udibonos; from around 6.13 in October 2001 to 5.94 in November 2002 in the case of PICs and from 6.16 and 6.21 percent in January 2003 to 4.59 and 4.68 percent in December 2005 in the case of 20 and 30 yr CBICs; while the technical rate used for pricing of 3.5 percent real has not been modified. Indeed, pension providers can add a 3 percent mark up for administrative costs and deviation in the mortality assumptions that has no effect on the annuity value because by law the pension is established considering defined benefits. Technical rate used for pricing should be liberalized (which would imply changes in the current legal constrains) or regularly analyzed to maintain it below expected long run interest rates. 
A third issue relates to the option extended to IV and RT annuitants to elect benefits under the LSS-73. A series of reforms in 2001 and 2002 have progressively reduced the generosity of IV benefits under the LSS-97 provisions relative to the LSS-73 provisions. For instance, the indexation base of pension benefits provided for under the LSS-73 was changed in 2001 from the minimum salary in the Federal District to the INPC. With the Mexican experience of very low wage inflation this resulted in a relatively lower attractiveness of IV benefits provided for under LSS-97. The change of the indexation base is considered a step in the good direction since experience suggests that wage inflation is on average higher than price inflation over long period of times. In addition price inflation is a more transparent index to follow that minimum wage inflation. Finally, minimum wages tend to be changed in many countries in an ad hoc fashion, following political motivations, which would have resulted in highly unpredictable benefit expenditure for the federal government. In 2002, a second reform of the LSS-97 was passed allowing individuals who elect benefits under the provision of LSS-73 to withdraw as a lump sum the balance of the 2 percent accumulate contributions for old age pension in the RCV subaccount. Such withdrawal is not allowed for people electing benefits under the LSS-97 provisions.

In 2002 the IMSS granted IV and RT insured individuals to elect benefits under the LSS73 provisions. This resulted in a sudden drop of gross premium income to the private sector pension annuity providers. In addition the IMSS tightened eligibility criteria in 2002 and started making a larger use of temporary IV pensions so that the individual who eventually end up purchasing IV or RT annuities from the private sector tend to live longer than anticipated.

There is a concern that insured individuals are not receiving adequate guidance for the IMSS at the moment of choice between benefits under the LSS-73 and LSS-97 provisions. In fact, even with the 2001 and 2002 reforms, IV pension benefits under the LSS-97 provisions are on average designed to be more generous. Hence, the government should give priority to enhance transparency in choosing benefits under the old and new system by putting in place a comprehensive election system for disabled workers. The IMSS has an incentive to allow individuals to elect benefits under the old system because, when that happens, the federal government is liable for paying benefits. If, on the contrary, insured individuals choose the new system, the IMSS has to use its own reserves to top up the disabled worker's pension fund balance in order to buy him/her an annuity in the market. It appears, therefore, that the financial position of the IMSS improves if disabled workers choose benefits under the old system. The IMSS, moreover, is not required by law to compare disability benefits under the two systems and disclose this comparison to the worker, unless the worker requests it. As a result of all this, the federal government is now funding a liability that was not foreseen under the 1997 pension reform. In order to improve the current situation, the government's liability should be clarified so as to ensure that IMSS is indifferent to whether disabled workers choose benefits under the old or new systems. The necessary actions should be taken in order to enhance transparency in choosing benefits under the new and old system, so that IMSS appropriately compares and discloses disability benefits under the two systems. Since benefits under the two provisions are heterogeneous, this may require deregulating annuity prices for private sector providers so that competition takes place only on the basis of basic benefits. 


\section{A final fourth issue relates to the ALM framework and its relationship to solvency.} Mexico has introduced capital requirements based, among other things, on a regulatory maturity gap weighting system between assets and liabilities. In addition companies are required to define their ALM frameworks on the basis of duration metrics to manage interest rate risk. Finally, inflation risk needs totally hedging. The ALM framework used in Mexico and its relationship to capital requirements and therefore, solvency embrace internationally recognized good practices of risk management, placing the CNSF on the frontier within the region as far as risk management is concerned. Nevertheless, three observations could be made on the current rule and practices.

The first observation relates to the fact that the regulatory maturity gap system based on the availability of the investment instruments compared with the total technical provision has very low weights on long term maturity gaps. The CNSF estimates that on average in a prudential scenario, with a reinvestment rate of 0 percent in real terms, a 25 percent increase in current levels of technical provisions would be required if weights were equal to unity at all maturities. This suggests that pension annuity providers would be incurring potential interest rate risk that regulations do not adequately disclose.

The second observation relates to the fact that the economic ALM framework that company needs developing does not seem to be related to capital requirements and solvency. An independent assessment of ALM practices would be required to provide technical assistance to the industry on how to improve the measuring, monitoring and management of interest rate risk. In this paper we suggest that the use of partial or key durations and convexities (complemented by the current maturity gap analysis) could represent an important improvement on current practices.

The third observation relates to the fact that longevity risk is completely born by annuity providers. We already suggested that life insurance companies would have a natural hedge for such risk in their pure death (or death related) portfolios. Longevity risk can also be shared with annuitants through longevity participating annuities where annuities are "re-priced" on a regular basis (every three or five years) depending on the mortality experience of the annuitant pool of each company. The CREF annuity provided by the US pension fund TIAA-CREF is a classic example, often quoted, of such risk sharing arrangement. Longevity risk can also be shared with the federal government or other international institutions by requiring providers to purchasing longevity-linked instruments such as longevity bonds. There is a quickly growing literature on longevitylinked instruments and the paper by Blake et al. (2006) in the reference section provides a useful starting point for further study.

Some less urgent issues relating to the investment rules for annuity companies could also be addressed in order to better enable these companies to hedge inflation, interest rate, and longevity risks. Despite companies can currently strip bonds to increase duration of assets they appear not to be able to easily find a counterpart to do so. The federal government may need to consider facilitating such matching by issuing zero coupon CPIindexed bonds as well as longevity bonds. In addition, authorities could consider allowing annuity companies, subject to appropriate regulatory framework, to buy interest rate swaps in the OTC market to better bridge duration mismatches. Finally, the CNSF could assess the current and prospective short term inflation risk for annuity companies and consider relaxing the inflation matching requirement for short term liabilities (below 
one year) as inflation indexed instruments with such short maturities are reported to be very illiquid. 


\section{REFERENCES}

[1] Blake, David, A. J. G. Cairns and K. Dowd (2006) Living with Mortality: longevity bonds and other mortality linked securities. Mimeo.

[2] CNSF (1998) Circular S-10.6.2: Reserva para Obligaciones Pendientes de Cumplir por Siniestros Ocurridos y No Reportados y Reserva de Gastos de Ajuste Asignado el Siniestro. Forma de entrega de la Información Estadística. (DOF; February 20, 1998);

[3] CNSF (1998a) Circular S-10.6.3: Reserva para Obligaciones Pendientes de Cumplir por Siniestros Ocurridos y No Reportados y Reserva de Gastos de Ajuste Asignado el Siniestro. Complemento a la Circular S-10.6. (DOF; November 24, 1998).

[4] CNSF (1999) Circular S-10.6.1: Reserva para obligaciones pendientes de cumplir por siniestros ocurridos y no reportados y reserva de gastos de ajuste asignados al siniestro. Envío de Formatos Estadísticos. (DOF; June 2, 1999)

[5] CNSF (2003) Circular S-10.1.2: Se dan a conocer a las instituciones y sociedades mutualistas de seguros, las disposiciones de carácter general para el registro de métodos actuariales de valuación y suficiencia de la reserva de riesgos en curso de los seguros de daños y accidentes y enfermedades. (Published on Federal Official Gazette, DOF, on September 30, 2003)

[6] CNSF (2003a) Circular S-10.1.7.1: Se dan a conocer a las instituciones y sociedades mutualistas de seguros, las disposiciones de carácter general para el establecimiento del método actuarial para la determinación del monto mínimo de la reserva de riesgos en curso de los seguros de vida. (DOF; September 30, 2003);

[7] CNSF (2003b) Circular S-10.1.7: Se dan a conocer a las instituciones y sociedades mutualistas de seguros, las disposiciones de carácter general para el registro de los métodos actuariales de valuación, constitución e incremento de la reserva de riesgos en curso de los seguros de vida. (DOF; September 30, 2003)

[8] CNSF (2003c) Circular S-10.6.6: Se dan a conocer a las instituciones y sociedades mutualistas de seguros, las disposiciones de carácter general para el registro de métodos actuariales para la estimación de la reserva para obligaciones pendientes de cumplir de siniestros respecto de los cuales los asegurados no han comunicado valuación alguna. (DOF; September 30, 2003).

[9] CNSF (2004) Circular S-10.1.8: Se dan a conocer a las instituciones y sociedades mutualistas de seguros, los estándares de práctica actuarial que deberán aplicarse para la valuación de las reservas técnicas. (DOF; June 1, 2004);

[10] CNSF (2005) Circular S-10.1.1: Reserva de Riesgos en Curso.- Se da a conocer la forma y términos en que deberán presentar la información de la valuación de las Reservas de Riesgos en Curso. (DOF; May 12, 2005).

[11] CNSF (2006) Comportamiento Del Mercado De Seguros De Pensiones Derivados De Las Leyes De La Seguridad Social (1997-2005). Mimeo.

[12] CNSF (2006a) Prudential Rules (ICP 6-10). Mimeo. 
[13] CNSF (2006b) Investment Regime and Solvency Margin. Mimeo.

[14] CNSF (2006c) Technical Reserves. Mimeo.

[15] CNSF (2006d) Annuities. Mimeo.

[16] CNSF (2006e) Dynamic Solvency Testing Models. Mimeo.

[17] CNSF (2006f) Tablas De Mortalidad De Los Seguros De Pensiones Derivados De Las Leyes De Seguridad Social. Mimeo.

[18] CNSF (2006g) Metodología De Cálculo De Las Primas Únicas (Montos Constitutivos) De Los Seguros De Pensiones Derivados De Las Leyes De Seguridad Social. Mimeo.

[19] CNSF (2006h) Esquema Regulatorio De Los Seguros De Pensiones Derivados De Las Leyes De Seguridad Social. Mimeo.

[20] CNSF (2006i) Comercialización Y Competencia En Los Seguros De Pensiones Derivados De Las Leyes De Seguridad Social. Mimeo.

[21] Cox, Samuel H. and Yijia Lin (2005) Natural Hedging of Life and Annuity Mortality Risks. Mimeo.

[22] Dettatreya, Ravi E. and Frank J. Fabozzi (1995) The Risk Point Method for Measuring and Controlling Yield Curve Risk. Financial Analyst Journal, Vol , pp. $45-54$.

[23] Dowd, K., D. Blake, A. J. G. Cairns, and P. Dawson (2004). Survivor swaps. Centre for Risk and Insurance Studies Working Paper no.7, University of Nottingham, Nottingham, UK.

[24] Fabozzi, Frank J., and H. Gifford Fong (1994) Advanced Fixed Income Portfolio Management (Probus Publishing, Chicago, Ill.).

[25] Fernandez Reyes, Maria del Carmen (2004) Seguro de Invalidez. Mimeo.

[26] Ho, Thomas Y. (1992) Key Rate Durations: Measures of Interest rate Risks. Journal of Fixed Income, Vol , pp. $29-44$.

[27] Holzeu, Thomas and Roman Lechner (2006) Measuring underwriting profitability of the non-life insurance industry. Swiss Re Sigma No 3/2006.

[28] Reitano, Robert R. (1992) Non-parallel Yield Curve Shifts and Immunization. Journal of Portfolio Management, Vol , pp. 36 - 43.

[29] SHCP (1997) Reglas de operación para los seguros de pensiones, derivados de la leyes de seguridad social.

[30] SHCP (2000) Reglas para la inversión de las reservas técnicas de las instituciones y sociedades mutualistas de seguros, (DOF, August 8, 2000) 


\section{APPENDIX A : RegUlatory FrameWORK FOR PENSION ANNUITIES}

The following appendix lists the pieces of legislation and secondary regulations related to the market of pension annuities. ${ }^{36}$

\section{Table 22: Regulatory Framework for Pension Annuities (as of May 2006)}

Laws

General Insurance Law (LGISMS)

Rules

Operational rules for pension insurance companies created in accordance with the laws of social security: they establish specific regulation applicable to pension annuities. Rules for investments of technical reserves of insurance companies: they establish investment rules that pension institutions must follow to protect required technical reserves. Rules regarding minimum capital guarantee of insurance companies: they establish the methodologies to determine the gross solvency requirement, the allowable deductions to obtain the minimum capital guarantee, and the characteristics of the admitted assets.

\section{Circulars}

S-

22.1.2

S-

22.1.3

$\mathrm{S}-$

22.1.4

S-

22.1.5

S-

22.1.6

S-22.2

S-22.3

S-

22.3.1

$\mathrm{S}-$

22.3.2

$\mathrm{S}-$

22.3.3
Technical criteria and administrative dispositions for effects of the application of the operational rules of pension annuities

Commercialization: the criteria for the activities of intermediation for the commercialization of pension annuities

Special fund: the form and terms of contributions

Modification to the $98^{\text {th }}$ Article of Operational Rules for pension annuities

Addition of a Transitory Article to the Agreement, which changed the $98^{\text {th }}$ Article of the Operational Rules for pension insurances, as well as the reform of the $108^{\text {th }}$ of its Own Rules

\section{Technical assumptions for the pension annuities}

Technical note in the basic benefits and dispositions for the registration of technical bases of additional benefits for pension annuities

Criteria and procedures that should be utilized in the calculation of the net premium reserve (PNR) of pension annuities

General criteria related to additional benefits of pension insurances

General criteria related to the services that insurance institutions are authorized to promote in offering pension annuities

\footnotetext{
${ }^{36}$ This Appendix was kindly prepared by the CNSF and reported here as a mere reference. All documents here listed can be accessed at www.cnsf.gob.mx.
} 


\section{Circulars}

$\mathrm{S}-$

S-

S-22.4

S-22.5

S-22.7

S-

22.7.1

$\mathrm{S}-$

22.7.2

$\mathrm{S}-$

S-22.8

S-22.9

S-

22.10

S-

22.10 .1

S-

S-

22.12

S-

22.13

S-

22.14

S-

22.15

\section{Oficio}

Circulars

S-38/01

S-231/97

Source: CNSF.
Single technical note and technical criteria pertaining to basic benefits of the life incomes for the beneficiaries of old age pension annuities, in advanced age with guaranteed pensions

Increment to pensions that refer to the $14^{\text {th }}$ Transitory Article modified according to the Decree, through which the $14^{\text {th }}$ and the $24^{\text {th }}$ Transitory Articles of the Decree are reformed and added. They modify and add to the Social Security Law. Methodologies for the decision of the net premium, total constituents, and the criteria for their granting

Contractual documentation for basic benefits of pension annuities

Structure of the statistical system to be used by pension annuities

Methods for the valuation of technical reserves of the pension annuities stemming from the laws of social security.

Technical criteria and administrative dispositions for the valuation of pension annuity reserves

Criteria and technical procedures to evaluate the obligations pertaining to policies written in subsequent months from the resolution date

Operational and technical criteria for the refund of resources to the Mexican Institute of Social Security in the case of cancellation of life income and/or survival insurance by inappropriateness

Special Mathematical Reserve: forms and terms for its effects

Minimum standards for the marketing pamphlet that should be enclosed to policies of pension annuities

The content of basic benefits offered by pension annuities

General criteria of additional benefits offered by pension annuity companies

Operational and technical dispositions for the suspension of pension payments, family assignments, and Christmas bonuses for children or orphans between 16 and 25 years of age

Death of pensioners and beneficiaries: applicable operational and technical criteria for pensions provided due to disability and life, and work-risks

Operational and technical dispositions for the processing of additional income for widows with retirement benefits equal or smaller to 1.5 minimum wage in the Federal District

Constitutional dispositions for the establishment and accounting registration of reserves associated with non-complied pending obligations

Procedure for verification of pensioner survival. It is made known the dispositions that should be followed for its implementation

Capital requirements due to the mismatching between assets and liabilities. Disclosure of the rates that those institutions should utilize for its determination

It is reiterated the criteria for accounting registration and technical reserves valuation, as well as the dispositions related to the form of presenting offers of basic benefits by pension insurances. 


\section{APPENDIX B : LIST OF ACRONYMS}

\begin{tabular}{|c|c|}
\hline AFORE & Administradora de Fondos para el Retiro \\
\hline CBIC & Certificados Bursátiles de Indemnización Carretera \\
\hline CNSF & Comisión Nacional de Seguros y Fianzas \\
\hline CONAC & Colegio Nacional de Actuarios de México \\
\hline CONAPO & Consejo Nacional de Población \\
\hline CONSAR & Comisión Nacional del Sistema de Ahorro para el Retiro \\
\hline CR & Combined Ratio $=\mathrm{LR}+\mathrm{OR}+\mathrm{UR}$ \\
\hline IBNR & Incurred But Not Reported Claims Reserve \\
\hline IMSS & Instituto Mexicano del Seguro Social \\
\hline INFONAVIT & Instituto Del Fondo Nacional De La Vivienda Para Los Trabajadores \\
\hline IOSCO & International Organization of Securities Commissions \\
\hline ISSSTE & $\begin{array}{l}\text { Instituto De Seguridad Y Servicios Sociales De Los Trabajadores Del } \\
\text { Estado }\end{array}$ \\
\hline IV & Invalidez y Vida \\
\hline LGISMS & Ley General de Instituciones y Sociedades Mutualistas de Seguros \\
\hline LR & Loss Ratio \\
\hline LSAR & Ley de los Sistemas de Ahorro para el Retiro \\
\hline LSS-73 & Ley de Seguro Social de 1973 \\
\hline LSS-97 & Ley de Seguro Social de 1997 \\
\hline NPR & Net Premium Reserve (or mathematical reserve) \\
\hline OR & Operacional Expense Ratio \\
\hline PMG & Pensión Mínima Garantizada \\
\hline RBS & Requerimiento Bruto de Solvencia \\
\hline $\mathrm{RCV}$ & Retiro, Cesantía en Edad Avanzada y Vejez \\
\hline RIRT & Reglas para la Inversión de las Reservas Técnicas \\
\hline RMA & Rendimiento Mínimo Acreditable \\
\hline RT & Riesgo de Trabajo \\
\hline SAR & Sistema de Ahorro para el Retiro \\
\hline SAR-02 & Sistema de Ahorro para el Retiro (reforma de 2002) \\
\hline SAR-92 & Sistema de Ahorro para el Retiro (reforma de 1992) \\
\hline SAR-97 & Sistema de Ahorro para el Retiro (reforma de 1997) \\
\hline SHCP & Secretaria de Hacienda y Crédito Publico \\
\hline SIC & Sistema Internacional de Cotizaciones \\
\hline SIEFORE & Sociedad Especializada de Fondos para el Retiro \\
\hline SINCAS & Sociedades de Inversión de Capitales \\
\hline UDIBONOS & $\begin{array}{l}\text { Bonos De Desarrollo Del Gobierno Federal Denominados En Unidades } \\
\text { De Inversión }\end{array}$ \\
\hline UPR & Unearned Premium Reserve \\
\hline UR & Underwriting Expense Ratio \\
\hline
\end{tabular}

